\title{
An Optimal Redesign Approach for Optimal Global Supply Chain Redesign: Brazilian Soybean Grain Study
}

\author{
Juan José Uchuya Lopéz \\ Department of Ocean Engineering, the Federal University of Rio de Janeiro, Brazil \\ E-mail: juanjouchuya@gmail.com \\ Raad Yahya Qassim \\ Department of Ocean Engineering, the Federal University of Rio de Janeiro, Brazil \\ E-mail: raadqassim@hotmail.com
}

Received: Nov. 17, 2017 Accepted: Nov. 29, 2017 Published: Dec. 12, 2017

doi:10.5296/bmh.v5i2.12284 URL: http://dx.doi.org/10.5296/bmh.v5i2.12284

\begin{abstract}
Brazil and the United States are the leading soybean grain producing and exporting countries in the world. Although crop production cost is significantly lower in Brazil than in the United States due to more advanced crop production technology, this competitive advantage vanishes in view of the higher logistics costs in Brazil than in the United States, in view of the dominance of road transportation in Brazil, whilst river and rail transportation are prevalent in the United States. In order to regain its competitive advantage, there is a clear need for a redesign of the inland supply chain in Brazil through the use and expansion of existent inland waterways and rail networks. In this paper, an optimal supply chain redesign methodology is presented to achieve the aforesaid objective, with a focus on Mato Grosso which is the largest producer and exporting state in Brazil. This methodology is in fact applicable to multiply echelon global supply chains in general.
\end{abstract}

Keywords: Global supply chains, Optimal redesign, Model decomposition, Soybean grain

\section{Introduction}

Supply chain redesign (SCRD) may be defined as the restructuring of an existent supply chain with a view to adding value to the end customer of an enterprise. SCRD is carried out in view of new business conditions and/or new strategic objectives. SCRD can be achieved by the integration of material and information flows, along with the utilisation of technology and other resources, towards the creation and enhancement of value to the end customer 
(Handfield \& Nichols, 2002).

SCRD and supply chain design (SCD), though sharing many attributes, are distinct in one fundamental aspect. In SCD, a new and inexistent supply chain is structured so as to achieve one or more objectives (e.g., monetary revenue, delivery cost, and delivery time), subject to various constraints (e.g., production capacity, transportation capacity, and budgetary limits). In contrast, in SCRD an existent supply chain is restructured, so as to achieve the same type of objective(s) subject to the same type of constraints, but with additional ones comprising the opening of new facilities and closing of existent facilities, as well as existent facility capacity expansion and reduction at one or more echelons of the supply chain under consideration. In view of the very nature of the SCD and the SCRD problems (objective achievement subject to constraints), the most widely approach adopted for their formulation is that of mathematical programming (Nagurney, 2010; Ghaderi Cortinal et al., 2015; Ghaderi et al., 2016). Van Der Vorst \& Beulens (1999) provide a framework for supply chain redesign with application in the food industry.

The work that is reported in this paper is concerned with the redesign of one type of supply chain which may be characterised as a global four echelon supply chain. Global supply chains arise in enterprises that operate in global markets, and in two contexts, the first of which occurs when an enterprise is motivated by cost reduction and productivity increase to outsource its non-core operations, such as the supply of raw materials and components, to countries and regions in other continents, with a view to increasing their competitive advantage (Ibrahim et al., 2015). In the second context whereby a global supply chain is encountered occurs when an enterprise produces one or more commodities in one continent, such as the case of mineral ores and grain crops, which are exported to markets in other continents. It is the latter type of global supply chain and associated redesign problem which is the concern of the work which is presented in this paper. Such a global supply chain normally consists of four echelons: production centres, storage/intermodal terminals, exportation ports, and importation ports, from which the commodity is distributed to consumers. The facilities in the first three echelons are located in one continent, whilst the facilities in the fourth echelon are located in other continents. An example of such a supply chain may be found in (Zucchi et al., 2011) where the beef export supply chain in the State of Mato Grosso, Brazil, is considered, and a mathematical programming model is presented to determine the optimum location of slaughterhouses in the second echelon of the aforesaid supply chain.

The motivation of the work presented in this paper lies in the necessity of the redesign of the soybean grain export supply chain in Brazil. Brazil and the United States are the two leading soybean grain producing and exporting countries in the world (Taylor \& Koo, 2015). Whilst production costs in Brazil are significantly lower than in the US due to more advanced crop production technology, inland logistics and transportation costs in Brazil are substantially higher than in the US, in view of the fact that the dominant transportation mode of soybean grain in Brazil is road (Reis \& Leal, 2015), in contrast to that in the US whose dominant transportation modes of soybean grain are inland waterways (Clott et al., 2015) and rail (Hyland et al., 2016), whose costs are significantly lower than that of road transportation. 
Bearing in mind that in Brazil there exists an extensive inland waterways network which is significantly underused and the ongoing introduction of rail transportation, it is clear that the soybean supply chain in Brazil needs to be redesigned, so as to incorporate inland waterways and rail transportation into the existent soybean grain supply chain. A major element of the aforesaid redesign is the introduction of road-water, rail-water, and rail-road intermodal terminals; furthermore, in view of the expansion of soybean production from the southeastern region of Brazil towards the northern and northeastern regions of Brazil, existent exportation port capacity expansion as well as new exportation port development in the northern and northesatern regions of Brazil are an essential part of the redesign of the soybean supply expansion in Brazil. The first step in the aforesaid redesign task is carried out by the development of a general mathematical programming model, and its application to a real life case study with focus on the State of Mato Grosso, which is the largest soybean producer and exporter in Brazil. It is this first step that constitutes the concern of this paper.

The remainder of the paper is organised as follows. In Section 2, a description of the problem is provided which includes the formulation of a novel mathematical bilevel programming model for the problem. In view of the complexity and intractability of the aforesaid model, its decomposition into three more tractable submodels is proposed, and the aforesaid submodels are put into computational algorithmic form. The aforsaid decomposition scheme is applied to a real life case study based on the State of Mato Grosso, Brazil. A sensitivity analysis of the results is presented in Section 3. The paper is concluded in Section 4 by an assessment of the modelling approach, its applicability to four echelon supply chains in general, and indication of future research directions as a followup to the work which is presented in this paper.

\section{Method}

\subsection{Problem Description}

The general objective of the supply chain redesign problem under consideration in this paper is the determination of a joint optimal plan for investment in logistics infrastructure at the second and third echelons of the supply chain and for logistics operating costs of the supply chain as a whole. Logistics infrastructure investment cost comprises the opening and of new intermodal terminals, capacity expansion of existent intermodal terminals, new exportation port development, and capacity expansion of existent exportation ports. Logistics operating cost covers material handling and transportation processes.

Material is produced and moved through such a global four echelon supply chain though the echelons of the supply chain as follows.

(1) A first echelon which consists of a set of existent crop production centres, with each of which is associated a known material supply amount.

(2) A second echelon which consists of a set of potential intermodal terminals, some of which are existent and others which can be built (opened) terminals. The term potential intermodal terminal is used to depict existent as well as yet-to-be-built terminals, in view of the fact that an existent intermodal terminal may not be part of those selected (as a result of the solution of 
the problem) to be actually used. Clearly, if an existent intermodal terminal were to be selected, then its opening cost is either zero or its selection corresponds to a predefined capacity expansion level. Furthermore, a production centre may be connected by one or more transportation links (normally, but not necessarily, each transportation link implies a different transportation mode) to an intermodal terminal. When there is more than one transportation link between a production centre and an intermodal terminal, then that intermodal terminal is split (solely for the purpose of the modelling of the problem) into a number of intermodal terminals which equals the number of transportation links. Thus, after such splitting, there will be only one transportation link between a production centre-intermodal terminal pair. This means that the number of intermodal terminals is effectively increased (solely for modelling purposes of the problem). Furthermore, if a production centre may be linked directly to an exportation port, then that exportation port is considered as a separate intermodal terminal (solely for the purpose of the modelling of the problem) with a predefined fraction of its total capacity. This means that the number of intermodal terminals is effectively increased (solely for the purpose of modelling of the problem). In view of the fact that storage cost at an intermodal terminal is sufficiently small in comparison with handling cost, it is neglected; furthermore, it is assumed that storage capacity at an intermodal terminal is unlimited.

(3) A third echelon which consists of a set of potential exportation ports, some of which are existent and others which can be built. The term potential exportation ports is used to depict existent as well as yet-to-be-built exportation ports, in view of the fact that an existent exportation port may not be part of those selected (as a result of the solution of the problem) to be actually used. Clearly, if an existent intermodal terminal were to be selected, then its opening cost is either zero or it corresponds to a predefined level of capacity expansion. Furthermore, an intermodal terminal may be connected by one or more transportation links (normally, but not necessarily, each transportation link implies a different transportation mode) to an exportation port. When there is more than one transportation link between a an intermodal terminal and an exportation port, then that exportation port is split (for the purpose of the modelling of the problem) into a number of exportation ports which equals the number of transportation links. Thus, after such splitting, there will be only one transportation link between an intermodal terminal-exportation port pair, and the number of exportation ports is effectively increased. It is assumed that a production centre is connected to an exportation port through one intermodal terminal at most; i.e., the connection between a production centre and an exportation port does not have more than one intermodal terminal in between. In view of the fact that storage cost is sufficiently small at an exportation port in comparison with handling cost, it is neglected; furthermore, it is assumed that storage capacity at an exportation port is unlimited.

(4) A fourth echelon which consists of a set of existent importation ports, with each of which there is associated a known demand. The port is assumed to have sufficient capacity to handle as much material flow as is necessary, and the allocation of a finite capacity to each exportation port is considered to be outside the scope of this work.

On the one hand, transportation link costs between successive echelons in the supply chain 
are taken into account; however, on the other hand, transportation link capacities are assumed unlimited. This assumption is considered valid as grain transportation flow is for the most part a small fraction of total transportation flow, which comprises other commodities, general cargo, and passenger transportation in existent transportation links in the supply chain network.

It is clear from the last pair of paragraphs that there are two types of decision makers at each of the second and third echelons of the supply chain: one decision maker needs to determine the least investment cost in logistics infrastructure (intermodal terminals and exportation ports in the second and third echelons, respectively), who is referred to as the investor, and the other decision maker needs to determine the least operating cost in all echelons, who is referred to as the user. The decisions that are made by the investor and the user are interdependent and are also subject to various constraints of material balances, supplies, demands, production capacities, handling capacities, and transportation modes between facilities of different echelons within the supply chain. Furthermore, it is assumed that the decision makers, investor and user, are partially cooperative in their decisions (Cao \& Leung, 2002), the justification for this assumption being that the decision makers in this problem have a common general objective, which is the determination of the least redesign cost of the four echelon supply chain as a whole. This is so because the user needs to cooperate with the investor, in order to use the facilities (intermodal terminals and exportation ports at the second and third echelons, respectively) and the investor needs to cooperate with the user in view of the fact that transportation infrastructure investments are made in order to reduce operating costs of the user. In practice, cooperation is enhanced between facilities within the supply chain, through information exchange and communication; cf., (Bahinipati et al., 2009; Thomas et al., 2015).

In view of the presence of two decision makers at the second and third supply chains of the supply chain under consideration, with each of whom an objective function is associated, a bilevel programming (BLP) modelling approach is adopted, whereby the investor and the user are the upper level and lower level decision makers, respectively, within the BLP modelling framework. There exists an appreciable amount of reported work on the employment of BLP in the formulation and solution of SCD; however, this is not the case in SCRD, where the use of BLP modelling is scarce (Cao \& Chen, 2006; Yeh et al., 2014; Yeh et al., 2015; Anu et al., 2015; Amitheri et al., 2016; Zhang et al., 2016).

\subsection{Four echelon mathematical programming model}

The four echelon supply chain redesign problem which is described in Section 2.1 may be stated as the following mathematical programming model, whereby notation is provided in Appendix A.

$$
\text { Minimise } \mathrm{z}_{1}=\sum_{\mathrm{j} \in \mathrm{J}} \mathrm{f}_{\mathrm{j}} \mathrm{y}_{\mathrm{j}}+\sum_{\mathrm{j} \in \mathrm{J}} \mathrm{p}_{\mathrm{j}}\left(\mathrm{Cap}_{\mathrm{j}} \mathrm{y}_{\mathrm{j}}-\Sigma_{\mathrm{i} \in \mathrm{JSj}} \mathrm{d}_{\mathrm{i}} \mathrm{x}_{\mathrm{ij}}\right)
$$

subject to

$$
\text { Minimise } \mathrm{z}_{2}=\sum_{\mathrm{j} \in \mathrm{J}} \mathrm{W}_{\mathrm{j}}\left(\sum_{\mathrm{i} \in \mathrm{J}} \mathrm{S}_{\mathrm{j}} \mathrm{d}_{\mathrm{i}} \mathrm{x}_{\mathrm{ij}}\right)+\sum_{\mathrm{i} \in \mathrm{I}} \mathrm{S}_{\mathrm{j}} \sum_{\mathrm{j} \in \mathrm{J}} \mathrm{d}_{\mathrm{i}} \mathrm{R}_{\mathrm{ij}} \mathrm{x}_{\mathrm{ij}}
$$




\section{Mll Macrothink}

subject to

$$
\begin{gathered}
\sum_{\mathrm{j} \in \mathrm{ISi}} \mathrm{x}_{\mathrm{ij}}=1, \mathrm{i} \in \mathrm{I} \\
\sum_{\mathrm{i} \in \mathrm{J}} \mathrm{S}_{\mathrm{j}} \mathrm{d}_{\mathrm{i}} \mathrm{x}_{\mathrm{ij}} \leq \mathrm{Cap}_{\mathrm{j}} \mathrm{y}_{\mathrm{j}}, \mathrm{j} \in \mathrm{J} \\
\sum_{\mathrm{i} \in \mathrm{I}} \mathrm{S}_{\mathrm{j}} \mathrm{x}_{\mathrm{ij}} \leq \mathrm{I} \mathrm{y}_{\mathrm{j}}, \mathrm{j} \in \mathrm{J} \\
\mathrm{x}_{\mathrm{ij}} \geq 0, \mathrm{y}_{\mathrm{i}} \in\{0,1\}, \mathrm{i} \in \mathrm{J} \mathrm{S}_{\mathrm{j}} ; \mathrm{j} \in \mathrm{J} \\
\text { Minimise } \mathrm{z}_{3}=\sum_{\mathrm{k} \in \mathrm{K}} \mathrm{f}_{\mathrm{k}} \mathrm{y}_{\mathrm{k}}+\sum_{\mathrm{k} \in \mathrm{K}} \mathrm{p}_{\mathrm{k}}\left(\operatorname{Cap}_{\mathrm{k}} \mathrm{y}_{\mathrm{k}}-\sum_{\mathrm{jj}} \in \mathrm{KSk} \mathrm{d}_{\mathrm{jj}} \mathrm{x}_{\mathrm{jj}, \mathrm{k}}\right)
\end{gathered}
$$

subject to

$$
\text { Minimise } \mathrm{z}_{4}=\sum_{\mathrm{k} \in \mathrm{K}} \mathrm{W}_{\mathrm{k}}\left(\sum_{\mathrm{jj} \in \mathrm{K}} \mathrm{S}_{\mathrm{k}} \mathrm{d}_{\mathrm{jj}} \mathrm{x}_{\mathrm{jj}, \mathrm{k}}\right)+\sum_{\mathrm{jj} \in \mathrm{KSk}} \sum_{\mathrm{k} \in \mathrm{K}} \mathrm{d}_{\mathrm{jj}} \mathrm{R}_{\mathrm{jj}, \mathrm{k}} \mathrm{x}_{\mathrm{jj}, \mathrm{k}}
$$

subject to

$$
\begin{aligned}
& \sum_{\mathrm{k} \in \mathrm{JJS} \mathrm{jj}} \mathrm{x}_{\mathrm{jj}, \mathrm{k}}=1, \mathrm{jj} \in \mathrm{JJ} \\
& \sum_{\mathrm{jj} \in \mathrm{KSk}} \mathrm{d}_{\mathrm{jj}} \mathrm{x}_{\mathrm{jj}, \mathrm{k}} \leq \mathrm{Cap}_{\mathrm{k}} \mathrm{y}_{\mathrm{k}}, \mathrm{k} \in \mathrm{K} \\
& \sum_{\mathrm{jj} \in \mathrm{KSk}} \mathrm{x}_{\mathrm{jjk}} \leq \mathrm{JJ}_{\mathrm{k}}, \mathrm{k} \in \mathrm{K} \\
& \mathrm{x}_{\mathrm{jj}, \mathrm{k}} \mathrm{y}_{\mathrm{k}} \in\{0,1\}, \mathrm{jj} \in \mathrm{KSk} ; \mathrm{k} \in \mathrm{K} \\
& \text { Minimise } \mathrm{z}_{5}=\sum_{\mathrm{l} \in \mathrm{L}} \mathrm{W}_{\mathrm{l}} \sum_{\mathrm{kk} \in \mathrm{KK}} \mathrm{d}_{\mathrm{kk}} \mathrm{x}_{\mathrm{kk}, 1}+\sum_{\mathrm{kk} \in \mathrm{KK}} \sum_{\mathrm{l} \in \mathrm{L}} \mathrm{d}_{\mathrm{kk}} \mathrm{R}_{\mathrm{kk}, 1} \mathrm{x}_{\mathrm{kk}, 1}
\end{aligned}
$$

subject to

$$
\begin{aligned}
& \sum_{\mathrm{l} \in \mathrm{L}} \mathrm{x}_{\mathrm{kk}, \mathrm{l}}=1, \mathrm{kk} \in \mathrm{KK} \\
& \sum_{\mathrm{kk} \in \mathrm{KK}} \mathrm{d}_{\mathrm{kk}} \mathrm{x}_{\mathrm{kk}, \mathrm{l}} \geq \operatorname{Dem}_{\mathrm{l}}, \mathrm{l} \in \mathrm{L} \\
& \mathrm{x}_{\mathrm{kk}, \mathrm{l}} \geq 0, \mathrm{kk} \in \mathrm{KK} ; 1 \in \mathrm{L}
\end{aligned}
$$

Objective function (1) depicts the investor's logistics infrastructure cost in the second echelon of the supply chain, whilst objective function (2) depicts the user's logistics cost in the first and second echelons of the supply chain. This pair of objective functions corresponds, from a bilevel programming point of view, to the upper and lower level decision making in the first and second echelons of the supply chain. Constraints (3) ensure that all material produced in a production centre is transported to intermodal terminals. Constraints (4) ensure that incoming material flow does not exceed material handling capacity for each intermodal terminal that is selected. Constraints (5) ensure that material flows from production centres to an intermodal terminal occur if and only if that intermodal terminal is selected. Constraints (5) and (6) define the domains of the decision variables of the first and second echelons of the supply chain.

Objective function (7) depicts the investor's cost in the third echelon of the supply chain, whilst objective function (8) depicts the user's cost in the third and fourth echelons of the supply chain. This pair of objective functions corresponds, from a bilevel programming point of view, to the upper and lower levels of decision making in the third and fourth echelons of the supply chain. Constraints (9) ensure for each intermodal terminal that is selected, all 
material handled is transported to exportation ports. Constraints (10) ensure that incoming material flow does not exceed handling capacity for each exportation port. Constraints (11) ensure that material flows from intermodal terminals to an exportation port occur if and only if that exportation port is selected. Constraints (12) define the domains of the decision variables of the second and third echelons of the supply chain.

Objective function (13) depicts the user's cost in maritime transportation from exportation ports to importation ports. Constraints (14) ensure that for each exportation port all material handled is transported to importation ports. Constraints (15) ensure that material demand is met at each importation port. Constraints (16) define the domain of the decision variables of the third and fourth echelons of the supply chain.

It is clear that the mathematical programming model defined by (1)-(16) is extremely complex and intractable as it stands. An extensive literature search on the optimal redesign of supply chains has shown that this problem has not been considered up to date, and consequently there does not exist any modelling approach to solve the model defined by (1)-(16). Thus, a decomposition of the model into three submodels is adopted. In submodel 1, a bilevel programming model is formulated for the first and second echelons of the original supply chain, and the solution of this submodel would determine the subset of intermodal terminals which are selected. In submodel 2, a bilevel programming model is formulated for the second and the third echelons of the original supply chain, and the solution of this submodel would determine the subset of exportation ports which are selected. In submodel 3, a monolevel programming model is formulated, with a view to the determination of material flows between exportation and importation ports.

The aforesaid decomposition scheme is motivated by the bilevel programming modelling approach for the redesign of two echelon supply chains that is presented by Cao and Chen (2006), whereby a bilevel program (BLP) is transformed exactly into a monolevel programming (MLP) model, which is significantly easier to solve that the original BLP. Summing up, the proposed decomposition scheme is based on the use of the aforesaid BLP modelling approach to decompose the model defined by (1)-(16) into three submodels is as follows.

Submodel 1. A BLP for the first and second echelons of the supply chain, which is transformed exactly to an MLP model (Cao \& Chen 2006). The aforesaid MLP model is defined in Appendix B.

Submodel 2. A BLP model for the second and third echelons of the supply chain, which is transformed exactly to an MLP model (Cao \& Chen 2006). The aforesaid MLP model is defined in Appendix B.

Submodel 3. A MLP model for the third and fourth echelons of the supply chain.

\subsubsection{Submodel 1}

In submodel 1, there are two echelons, corresponding to the first and second echelons of the original supply chain. A production centre may be connected by one or more transportation 
links (normally, but not necessarily, each transportation link implies a different transportation mode) to an intermodal terminal. When there is more than one transportation link between a production centre and an intermodal terminal, then that intermodal terminal is split (for purposes of modelling) into a number of intermodal terminals which equals the number of transportation links. Thus, after such splitting, there will be one and only one transportation link between a production centre-intermodal terminal pair. For an intermodal terminal that is yet-to-be-built, an investment would be necessary if the aforesaid intermodal terminal were to be selected (an existent terminal needs no such investment or only needs investment for a predefined capacity expansion level if it were selected). Furthermore, if a production centre is connected directly to an exportation port, then an intermodal terminal is added (for purposes of modelling) to the upper echelon, with a predefined fraction of the capacity of that port. The cost of logistics infrastructure investment in the second echelon of the supply chain (opening new intermodal terminals and expanding the capacity of existent terminals) is incurred by the investor, whilst the cost of the joint operation of the first and second echelons of the supply is incurred by the user. Then, submodel I may be stated as a bilevel programming model as follows.

$$
\text { Minimise } z_{1}=\sum_{j \in J} f_{j} y_{j}+\sum_{j \in J} p_{j}\left(C a p_{j} y_{j}-\sum_{i \in J S j} d_{i} x_{i j}\right)
$$

subject to

$$
\text { Minimise } \mathrm{z}_{2}=\sum_{\mathrm{j} \in \mathrm{J}} \mathrm{w}_{\mathrm{j}}\left(\sum_{\mathrm{i} \in \mathrm{JSj}} \mathrm{d}_{\mathrm{i}} \mathrm{x}_{\mathrm{ij}}\right)+\sum_{\mathrm{i} \in \mathrm{JSj}} \sum_{\mathrm{j} \in \mathrm{J}} \mathrm{d}_{\mathrm{i}} \mathrm{R}_{\mathrm{ij}} \mathrm{x}_{\mathrm{ij}}
$$

subject to

$$
\begin{aligned}
& \Sigma_{\mathrm{j} \in \mathrm{ISi}} \mathrm{x}_{\mathrm{ij}}=1, \mathrm{i} \in \mathrm{I} \\
& \Sigma_{\mathrm{i} \in \mathrm{JSj}} \mathrm{d}_{\mathrm{i}} \mathrm{x}_{\mathrm{ij}} \quad \leq \mathrm{Cap}_{\mathrm{j}} \mathrm{y}_{\mathrm{j}}, \mathrm{j} \in \mathrm{J} \\
& \Sigma_{\mathrm{i} \in \mathrm{J}} \mathrm{x}_{\mathrm{ij}} \leq \mathrm{I} \mathrm{y}_{\mathrm{j}}, \mathrm{j} \in \mathrm{J} \\
& \mathrm{x}_{\mathrm{ij}} \geq 0, \mathrm{y}_{\mathrm{i}} \in\{0,1\}, \mathrm{i} \in \mathrm{JSj}, \mathrm{j} \in \mathrm{J}
\end{aligned}
$$

Objective function (1) depicts infrastructure investment cost made by the investor in the second echelon of the original supply chain, whilst objective function (2) depicts operating cost incurred by the user in the first and second echelons of the original supply chain This pair of objective functions correspond, from a bilevel programming point of view, to the upper and lower levels of decision making, respectively. Constraints (3) ensure that for each production centre material produced therein is transported to intermodal terminals. Constraints (4) ensure that incoming material flow does not exceed incoming material handling capacity for each intermodal terminal that is selected. Constraints (5) ensure that material flows from production centres to an intermodal terminal occur if and only if that intermodal terminal were selected. Constraints (5) and (6) define the domains of the decision variables of the first and second echelons of the original supply chain.

\subsubsection{Submodel 2}

In submodel 2, there are two echelons, corresponding to the second and third echelons of the original supply chain. The upper echelon (which corresponds to the second echelon in the 
original supply chain) consists of a number of intermodal terminals which have been selected as determined by solving submodel 1 . The lower echelon (which corresponds to the third echelon in the original supply chain) consists of a number of exportation ports. Between each intermodal terminal - exportation port pair, there exists a transportation link. Then, submodel 2 may be stated as follows.

$$
\text { Minimise } \mathrm{z}_{3}=\sum_{\mathrm{k} \in \mathrm{K}} \mathrm{f}_{\mathrm{k}} \mathrm{y}_{\mathrm{k}}+\sum_{\mathrm{k} \in \mathrm{K}} \mathrm{p}_{\mathrm{k}}\left(\operatorname{Cap}_{\mathrm{k}} \mathrm{y}_{\mathrm{k}}-\sum_{\mathrm{jj} \in \mathrm{KSk}} \mathrm{d}_{\mathrm{jj}} \mathrm{x}_{\mathrm{jj}, \mathrm{k}}\right)
$$

subject to

$$
\text { Minimise } \mathrm{z}_{4}=\sum_{\mathrm{k} \in \mathrm{K}} \mathrm{W}_{\mathrm{k}}\left(\sum_{\mathrm{jj} \in \mathrm{KSk}} \mathrm{d}_{\mathrm{jj}} \mathrm{x}_{\mathrm{jj}, \mathrm{k}}\right)+\sum_{\mathrm{jj} \in \mathrm{KSk}} \sum_{\mathrm{k} \in \mathrm{K}} \mathrm{d}_{\mathrm{jj}} \mathrm{R}_{\mathrm{jj}, \mathrm{k}} \mathrm{x}_{\mathrm{jj}, \mathrm{k}}
$$

subject to

$$
\begin{gathered}
\sum_{\mathrm{k} \in J J S \mathrm{jj}} \mathrm{x}_{\mathrm{jj}, \mathrm{k}}=1, \mathrm{jj} \in \mathrm{JJ} \\
\sum_{\mathrm{jj} \in \mathrm{KSN} \text { djj } \mathrm{xjj}, \mathrm{k} \leq \text { Capk } \mathrm{yk}, \mathrm{k} \in \mathrm{K}} \\
\sum_{\mathrm{jj} \in \mathrm{KSk}} \mathrm{x}_{\mathrm{jj}, \mathrm{k}} \leq \mathrm{JJ}_{\mathrm{k}}, \mathrm{k} \in \mathrm{K} \\
\mathrm{x}_{\mathrm{jj}, \mathrm{k}}, \mathrm{y}_{\mathrm{k}} \in\{0,1\}, \mathrm{jj} \in \mathrm{KSk} ; \mathrm{k} \in \mathrm{K}
\end{gathered}
$$

Objective function (7) depicts the investment cost of exportation ports that are selected. At the lower level of decision making, objective function (8) depicts the operating cost of the second and third echelons of the original supply chain. Constraints (9) ensure that all material handled in intermodal terminals is transported to exportation ports that are selected. Constraints (10) ensure that the handling capacity of an exportation port is not exceeded if selected. Constraints (11) ensure that material is transported from intermodal terminals to an exportation port if and only if that exportation port were selected. Constraints (12) define the domains of the decision variables.

\subsubsection{Submodel 3}

The solution of submodel 2 provides a subset of exportation ports KK, which are to selected. Then, submodel 3 may be stated as follows.

$$
\text { Minimise } \mathrm{z}_{5}=\sum_{\mathrm{l} \in \mathrm{L}} \mathrm{w}_{1} \sum_{\mathrm{kk} \in \mathrm{KK}} \mathrm{d}_{\mathrm{kk}} \mathrm{x}_{\mathrm{kk}, 1}+\sum_{\mathrm{kk} \in \mathrm{KK}} \sum_{\mathrm{l} \in \mathrm{L}} \mathrm{d}_{\mathrm{kk}} \mathrm{R}_{\mathrm{kk}, 1} \mathbf{x}_{\mathrm{kk}, 1}
$$

subject to

$$
\begin{gathered}
\sum_{l \in \mathrm{L}} \mathrm{x}_{\mathrm{kl}}=1, \mathrm{kk} \in \mathrm{KK} \\
\sum_{\mathrm{kk} \in \mathrm{KK}} \mathrm{d}_{\mathrm{kk}} \mathrm{x}_{\mathrm{kk}, \mathrm{l}} \geq \mathrm{Dem}_{1}, 1 \in \mathrm{L} \\
\mathrm{x}_{\mathrm{kk}, \mathrm{l}} \geq 0, \mathrm{kk} \in \mathrm{KK} ; 1 \in \mathrm{L}
\end{gathered}
$$

Objective function (13) depicts the operating cost of the third and fourth echelons of the original supply chain. Constraints (14) ensure that all material handled in each selected exportation port is transported to importation ports. Constraints (15) ensure that demand is met at each importation port. Constraints (16) define the domain of the decision variables. 


\subsection{Computational Algorithms}

In this Section, an algorithm is presented for each submodel described in Subsections 2.2.1-2.2.3.

\subsubsection{Algorithm 1 for Submodel 1}

This algorithm consists of the following sequence of steps.

Step 1. For each intermodal terminal that has more than one transportation link to a production centre, split that terminal into a number of separate terminals (each having a predefined fraction capacity of that intermodal terminal) that equals the number of those links. Add each of those split terminals to the set of intermodal terminals.

Step 2. For each exportation port that has a direct transportation link to a production centre, add an intermodal terminal (with a predefined fraction of the capacity of that exportation port) to the set of potential intermodal terminals.

Step 3. Solve submodel 1 to determine the subset $\mathrm{JJ} \subset \mathrm{J}$ of intermodal terminals that are opened $(\mathrm{yj}=1)$ and the corresponding $\mathrm{x}_{\mathrm{ij}}$.

\subsubsection{Algorithm 2 for Subproblem 2}

This algorithm consists of the following sequence of steps.

Step 1. Consider the set JJ of intermodal terminal terminals and corresponding $\mathrm{x}_{\mathrm{ij}}$ as known which have been determined by the solution of submodel 1 . Note that

$$
\mathrm{d}_{\mathrm{jj}}=\sum_{\mathrm{i} \in \mathrm{JSj}} \mathrm{x}_{\mathrm{ij}} \mathrm{y}_{\mathrm{j}} \text {, if } \mathrm{y}_{\mathrm{j}}=1, \mathrm{jj} \subset \mathrm{j} \text {, and if } \mathrm{y}_{\mathrm{j}}=0, \mathrm{jj} \not \subset \mathrm{j} .
$$

Step 2. For each exportation port that has more than one transportation link to an intermodal terminal, split that exportation port into a number of separate exportation ports (each having a predefined fraction capacity of that exportation port) that equals the number of those links. Add each of those split exportation ports to the set of exportation ports.

Step 3. Solve submodel 2 to determine the subset $\mathrm{KK} \subset \mathrm{K}$ of exportation ports that are opened $\left(\mathrm{y}_{\mathrm{jj}, \mathrm{k}}=1\right)$ and the corresponding $\mathrm{x}_{\mathrm{jj}, \mathrm{k}}$.

\subsubsection{Algorithm for Submodel 3}

Step 1. Consider the set KK of exportation ports and corresponding $\mathrm{x}_{\mathrm{j} j \mathrm{k}, \mathrm{k}}$ as knowns, which have been determined by the solution of submodel 2 . Note that

$$
\mathrm{d}_{\mathrm{kk}}=\sum_{\mathrm{jj} \in \mathrm{KSk}} \mathrm{x}_{\mathrm{jj}, \mathrm{k}} \mathrm{y}_{\mathrm{k}} \text {, if } \mathrm{y}_{\mathrm{k}}=1, \mathrm{kk} \subset \mathrm{k} \text {, and if } \mathrm{y}_{\mathrm{k}}=0, \mathrm{kk} \not \subset \mathrm{k} .
$$

Step 2. Solve submodel 3.

\section{Results}

\subsection{Case Study}

In order to demonstrate the applicability of the mathematical programming model presented in Section 2, a real life case study has been considered, which is based on the State of Mato 


\section{Macrothink}

Grosso (MT), Brazil. The motivation for this selection lies in the fact that MT is the largest soybean producer and exporter of soybean in comparison with all other states in Brazil; furthermore the importance of MT to soybean consuming countries is clearly demonstrated by the case study of selected production regions in MT (Fliehr 2014).

\subsubsection{Subproblem 1}

For the purpose of this case study, the State of Mato Grosso has been divided into seven regions, each of which possesses one production centre (soybean grain elevator) where production from all farms within that region is consolidated; i.e., seven production centres constitute the first echelon of the supply chain.

The aforesaid production centres are connected to fifteen potential intermodal terminals by three types of transportation modes: road, rail, and inland waterway. The connectivity matrix is shown in Table 1. In the first and fifth rows, symbols are defined in Appendix A. The second and third rows of Table 1 denote the transportation modes of exit from and entry to an intermodal terminal, respectively. The fourth row in Table 1 indicates whether a potential intermodal terminal actually exists or needs to be built. In the firth row of Table, the symbols are defined in Appendix A. From the sixth to twelfth rows of Table 1, the symbols $\sqrt{ }$ and $x$, respectively, denote whether a transportation link exists or not between a production centre and an intermodal terminal. In Table 2, the distance in each existent link between a production centre and an intermodal terminal is presented in matrix form.

Table 1. Connectivity matrix of production centres and intermodal terminals

\begin{tabular}{|c|c|c|c|c|c|c|c|c|c|c|c|c|c|c|c|c|c|}
\hline \multicolumn{3}{|c|}{ Intermodal Terminal IT } & IT1 & IT2 & IT3 & \begin{tabular}{|l|} 
IT4 \\
\end{tabular} & \begin{tabular}{|l|} 
IT5 \\
\end{tabular} & IT6 & \begin{tabular}{|l|} 
IT7 \\
\end{tabular} & \begin{tabular}{|l|} 
IT8 \\
\end{tabular} & \begin{tabular}{|l|} 
IT9 \\
\end{tabular} & \begin{tabular}{|l|} 
IT10 \\
\end{tabular} & \begin{tabular}{|l|} 
IT11 \\
\end{tabular} & IT12 & IT13 & IT14 & IT15 \\
\hline \multirow{2}{*}{\multicolumn{2}{|c|}{$\begin{array}{c}\text { Type of Intermodal } \\
\text { Terminal } \\
\end{array}$}} & \multirow{2}{*}{$\rightarrow$} & $R A$ & $R A$ & $I W$ & $I W$ & $R A$ & $I W$ & $I W$ & $I W$ & $\mid I W$ & $R A$ & $R A$ & $M A$ & $M A$ & $M A$ & $M A$ \\
\hline & & & $R O$ & $R O$ & $R O$ & $R O$ & $R O$ & $R O$ & $R O$ & $R O$ & $R A$ & $R O$ & $R O$ & $R O$ & $R O$ & $R O$ & $R O$ \\
\hline \multicolumn{2}{|c|}{ IT Existent Y/N } & $\rightarrow$ & $\mathrm{Y}$ & $\mathrm{N}$ & $\mathrm{N}$ & $\mathrm{N}$ & $\mathrm{Y}$ & $\mathrm{Y}$ & $\mathrm{N}$ & $Y$ & $\mathrm{~N}$ & $\mathrm{~N}$ & $\mathrm{~N}$ & $Y$ & $\mathrm{Y}$ & $\mathrm{Y}$ & $\mathrm{Y}$ \\
\hline \multicolumn{2}{|c|}{ Production Center } & ISi & j1 & $\mathrm{j} 2$ & j3 & j4 & j5 & j6 & j7 & $\mathrm{j} 8$ & j9 & j10 & j11 & j12 & j13 & j14 & j15 \\
\hline ripu & PC1 & i1 & $x$ & $x$ & $x$ & $x$ & $x$ & $x$ & $\checkmark$ & $x$ & $x$ & $x$ & $x$ & $x$ & $x$ & $\checkmark$ & $x$ \\
\hline Itto $F$ & PC2 & i2 & $x$ & $x$ & $x$ & $x$ & $x$ & $x$ & $\checkmark$ & $x$ & $x$ & $x$ & $x$ & $x$ & $x$ & $\checkmark$ & $x$ \\
\hline Querênc & $\mathbf{P}$ & i3 & $\checkmark$ & $\checkmark$ & $\checkmark$ & $\checkmark$ & $\checkmark$ & $\checkmark$ & $x$ & $x$ & $x$ & $x$ & $\checkmark$ & $\checkmark$ & $\checkmark$ & $\checkmark$ & $\checkmark$ \\
\hline Sorriso & $\mathbf{P}$ & i4 & $\checkmark$ & $\checkmark$ & $\checkmark$ & $\checkmark$ & $\checkmark$ & $\checkmark$ & $\checkmark$ & $\checkmark$ & $x$ & $\checkmark$ & $\checkmark$ & $\checkmark$ & $\checkmark$ & $\checkmark$ & $\checkmark$ \\
\hline Sapeza & $\mathbf{P}$ & i5 & $\checkmark$ & $\checkmark$ & $\checkmark$ & $\checkmark$ & $\checkmark$ & $\checkmark$ & $\checkmark$ & $\checkmark$ & $x$ & $\checkmark$ & $\checkmark$ & $\checkmark$ & $\checkmark$ & $\checkmark$ & $\checkmark$ \\
\hline Uuiabá & $\mathbf{P C}$ & i6 & $\checkmark$ & $\checkmark$ & $\checkmark$ & $\checkmark$ & $\checkmark$ & $\checkmark$ & $\checkmark$ & $\checkmark$ & $\checkmark$ & $\checkmark$ & $\checkmark$ & $\checkmark$ & $\checkmark$ & $\checkmark$ & $\checkmark$ \\
\hline ondonópolis & PC7 & i7 & $\checkmark$ & $\checkmark$ & $\checkmark$ & $\checkmark$ & $\checkmark$ & $\checkmark$ & $\checkmark$ & $\checkmark$ & $x$ & $\checkmark$ & $\checkmark$ & $\checkmark$ & $\checkmark$ & $\checkmark$ & $\checkmark$ \\
\hline
\end{tabular}


Table 2. Distance matrix of production centres and intermodal terminals

\begin{tabular}{|c|c|c|c|c|c|c|c|c|c|c|c|c|c|c|c|c|c|}
\hline \multicolumn{3}{|c|}{ Intermodal Terminal IT } & IT1 & IT2 & IT3 & IT4 & IT5 & IT6 & IT7 & IT8 & IT9 & IT10 & IT11 & IT12 & IT13 & IT14 & IT15 \\
\hline \multirow{2}{*}{\multicolumn{2}{|c|}{$\begin{array}{c}\text { Type of Intermodal } \\
\text { Terminal } \\
\end{array}$}} & \multirow{2}{*}{$\rightarrow$} & $R A$ & $R A$ & IW & IW & $R A$ & $I W$ & IW & $I W$ & $I W$ & $R A$ & $R A$ & $\Lambda A$ & MA & MA & $M A$ \\
\hline & & & $R O$ & RO & RO & RO & RO & RO & $R O$ & $R O$ & $R A$ & RO & RO & 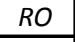 & 20 & O & RO \\
\hline \multirow{2}{*}{\multicolumn{2}{|c|}{ stances }} & 2 & 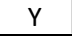 & IN & TV & $\Lambda$ & Y & & $\mathrm{N}$ & Y & $\mathrm{N}$ & $\mathrm{N}$ & $\mathrm{N}$ & I & & $Y$ & Y \\
\hline & & $\mathrm{Km}$ & j1 & j2 & ת & $\mathrm{JP}$ & j5 & 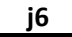 & 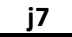 & j8 & 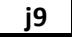 & j10 & j11 & 2 & J13 & 14 & j15 \\
\hline & & & 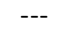 & -- & --- & -- & -- & -- & 37 & -- & --- & --- & --- & --- & -- & 1729 & --- \\
\hline & & & & -- & -- & -- & -- & -- & 30 & --- & -- & --- & --- & -- & -- & 1220 & --- \\
\hline & & i3 & 6 & 486 & 633 & 876 & 1118 & 112 & --- & --- & --- & --- & 836 & 2105 & 1657 & 2650 & 3284 \\
\hline & & 14 & 3 & 1662 & 1706 & 1949 & 2191 & 2202 & 771 & 1698 & --- & 66 & 419 & 3178 & 2730 & 1395 & 245 \\
\hline & & i5 & 48 & 1957 & 2081 & 2324 & 2566 & 2577 & 1576 & 97 & --- & 739 & 714 & 3553 & 3105 & 2200 & 1734 \\
\hline & & 10 & & 1243 & 1367 & 1610 & 1852 & 1863 & 1124 & 1687 & 1189 & 353 & 0 & 2839 & 2391 & 1814 & $244 \varepsilon$ \\
\hline ondon & & i7 & 1 & 116 & 1240 & 1483 & 1725 & 1736 & 1351 & 1914 & -- & 580 & 227 & 2712 & 2264 & 2041 & 667 \\
\hline
\end{tabular}

\subsubsection{Subproblem 2}

In similar fashion to subproblem 1 , the connectivity matrix between intermodal terminals and exportation ports is shown in Table 3. Ten exportation ports (EP1,..,EP10) are considered, out of which three (EP4, EP6, and EP8) represent capacity expansion in an existent port if selected or a new port to be built if selected through the solution of subproblem 2 . Three exportation ports are subdivided into two or three ports solely for the purpose of allowing for the multiplicity of transportation links of each of the aforesaid ports with production centres and intermodal terminals. This is the case of exportation port EP3 which is subdivided into EP3A and EP3B, exportation port EP5 which is subdivided into EP5A, EP5B, and EP5C, exportation port EP6 which is subdivided into EP7A and EP7B, exportation port EP7 which is subdivided into EP7A, EP7B, and EP\&C, and exportation port EP8 which is subdivided into EP8A and EP8B. As a result of the aforesaid subdivisions, there are in effect seventeen exportation ports under consideration, as shown in the first row of Table 3. The second and third rows of Table 3 indicate the transportation mode of exit from and entry to an exportation port, respectively. The fourth row of Table 3 indicates whether an exportation port exist or needs to be built. The symbols in the fifth row of Table 3 are defined in Appendix 1. From the sixth to twelfth rows of Table 3 , the symbols $\sqrt{ }$ and $x$, respectively, denote whether a transportation link exists or not between an intermodal terminal and an exportation port. It is worth noting that, in accordance with Table 3, intermodal terminal IT1 possesses two transportation links with exportation ports EP1 and EP2, one via rail and the other via road. Only the rail transportation link has been considered, with a view to limiting soybean grain flow to the southern ports and enhancing flow to northern and northeastern ports, this being the general objective of the soybean grain supply chain redesign in Brazil. 
Table 3. Connectivity matrix of intermodal terminals and exportation ports

\begin{tabular}{|c|c|c|c|c|c|c|c|c|c|c|c|c|c|c|c|c|c|c|c|}
\hline \multicolumn{3}{|c|}{ Exportation Port EP } & EP1 & EP2 & EP3A & EP3B & EP4 & EP5A & EP5B & EP5B & EP6A & EP6B & EP7A & EP7B & EP7C & EP8A & EP8B & EP9 & EP10 \\
\hline \multirow{2}{*}{\multicolumn{2}{|c|}{ Type of Exportation Port }} & \multirow{3}{*}{$\rightarrow$} & $M A$ & $M A$ & MA & MA & $M A$ & $M A$ & $M A$ & $M A$ & $M A$ & MA & $M A$ & $M A$ & $M A$ & MA & MA & $M A$ & $M A$ \\
\hline & & & $R A$ & $R A$ & $R O$ & $R A$ & $R A$ & $R O$ & $R A$ & $I W$ & $R A$ & $I W$ & $R O$ & $R A$ & $I W$ & $R A$ & $I W$ & $I W$ & $R O$ \\
\hline \multicolumn{2}{|l|}{ EP Existent $\mathrm{Y} / \mathrm{N}$} & & $\mathrm{Y}$ & $\mathrm{Y}$ & $\mathrm{Y}$ & $\mathrm{Y}$ & $\mathrm{N}$ & $\mathrm{Y}$ & $\mathrm{Y}$ & $\mathrm{Y}$ & $\mathrm{N}$ & $\mathrm{N}$ & $Y$ & $Y$ & $\mathrm{Y}$ & $\mathrm{N}$ & $\mathrm{N}$ & $\mathrm{Y}$ & $\mathrm{Y}$ \\
\hline \multicolumn{2}{|c|}{ Intermodal Terminal IT } & Isi & k1 & k2 & k3 & k4 & k5 & k6 & k7 & k8 & k9 & k10 & k11 & k12 & k13 & k14 & k15 & k16 & k17 \\
\hline Alto Araguaia & IT1 & j1 & $\checkmark$ & $\checkmark$ & $x$ & $x$ & $x$ & $x$ & $x$ & $x$ & $x$ & $x$ & $x$ & $x$ & $x$ & $x$ & $x$ & $x$ & $x$ \\
\hline Alvorada & IT2 & $\mathrm{j} 2$ & $x$ & $x$ & $x$ & $\checkmark$ & $\checkmark$ & $x$ & $\checkmark$ & $x$ & $\checkmark$ & $x$ & $x$ & $\checkmark$ & $x$ & $\checkmark$ & $x$ & $x$ & $x$ \\
\hline Peixe & IT3 & j3 & $x$ & $x$ & $x$ & $x$ & $x$ & $x$ & $x$ & $\checkmark$ & $x$ & $\checkmark$ & $x$ & $x$ & $x$ & $x$ & $x$ & $x$ & $x$ \\
\hline Conceição do Araguaia & IT4 & $\mathrm{j} 4$ & $x$ & $x$ & $x$ & $x$ & $x$ & $x$ & $x$ & $\checkmark$ & $x$ & $\checkmark$ & $x$ & $x$ & $x$ & $x$ & $x$ & $x$ & $x$ \\
\hline Marabá 1 & IT5 & j5 & $x$ & $x$ & $x$ & $x$ & $x$ & $x$ & $x$ & $\checkmark$ & $x$ & $\checkmark$ & $x$ & $x$ & $x$ & $x$ & $x$ & $x$ & $x$ \\
\hline Marabá 2 & IT6 & $\mathrm{j} 6$ & $x$ & $x$ & $x$ & $\checkmark$ & $\checkmark$ & $x$ & $\checkmark$ & $x$ & $\checkmark$ & $x$ & $x$ & $x$ & $x$ & $x$ & $x$ & $x$ & $x$ \\
\hline Santa Rosa & IT7 & j7 & $x$ & $x$ & $x$ & $x$ & $x$ & $x$ & $x$ & $x$ & $x$ & $x$ & $x$ & $x$ & $\checkmark$ & $x$ & $\checkmark$ & $x$ & $x$ \\
\hline Porto Velho - A & IT8 & j8 & $x$ & $x$ & $x$ & $x$ & $x$ & $x$ & $x$ & $x$ & $x$ & $x$ & $x$ & $x$ & $x$ & $x$ & $x$ & $\checkmark$ & $x$ \\
\hline Porto Velho - B & IT9 & j9 & $x$ & $x$ & $x$ & $x$ & $x$ & $x$ & $x$ & $x$ & $x$ & $x$ & $x$ & $x$ & $x$ & $x$ & $x$ & $\checkmark$ & $x$ \\
\hline Lucas do Rio Verde & IT10 & $\mathrm{j} 10$ & $x$ & $x$ & $x$ & $\checkmark$ & $\checkmark$ & $x$ & $\checkmark$ & $x$ & $\checkmark$ & $x$ & $x$ & $\checkmark$ & $x$ & $\checkmark$ & $x$ & $x$ & $x$ \\
\hline Cuiabá & IT11 & j11 & $x$ & $x$ & $x$ & $\checkmark$ & $\checkmark$ & $x$ & $\checkmark$ & $x$ & $\checkmark$ & $x$ & $x$ & $\checkmark$ & $x$ & $\checkmark$ & $x$ & $x$ & $x$ \\
\hline Itaqui & IT12 & $\mathrm{j} 12$ & $x$ & $x$ & $\checkmark$ & $x$ & $x$ & $x$ & $x$ & $x$ & $x$ & $x$ & $x$ & $x$ & $x$ & $x$ & $x$ & $x$ & $x$ \\
\hline Barcarena & IT13 & j13 & $x$ & $x$ & $x$ & $x$ & $x$ & $\checkmark$ & $x$ & $x$ & $x$ & $x$ & $x$ & $x$ & $x$ & $x$ & $x$ & $x$ & $x$ \\
\hline Santarém & IT14 & j14 & $x$ & $x$ & $x$ & $x$ & $x$ & $x$ & $x$ & $x$ & $x$ & $x$ & $\checkmark$ & $x$ & $x$ & $x$ & $x$ & $x$ & $x$ \\
\hline Manaus & IT15 & j15 & $x$ & $x$ & $x$ & $x$ & $x$ & $x$ & $x$ & $x$ & $x$ & $x$ & $x$ & $x$ & $x$ & $x$ & $x$ & $x$ & $\checkmark$ \\
\hline
\end{tabular}

In Table 4, the distance in each existent link between an intermodal terminal and an exportation port is presented in matrix form. It is worth noting that when a zero value is indicated in Table 4, the intermodal terminal in question is part of an exportation port, and a broken dash line implies the inexistence of a transportation link between the intermodal terminal — exportation port pair in question.

Table 4. Distances matrix of intermodal terminals and exportation ports

\begin{tabular}{|c|c|c|c|c|c|c|c|c|c|c|c|c|c|c|c|c|c|c|c|}
\hline \multicolumn{3}{|c|}{ Exportation Port EP } & EP1 & EP2 & EP3A & EP3B & EP4 & EP5A & EP5B & EP5B & EP6A & EP6B & EP7A & EP7B & EP7C & EP8A & EP8B & EP9 & EP10 \\
\hline \multirow{2}{*}{\multicolumn{2}{|c|}{ Type of Exportation Port }} & \multirow{3}{*}{$\begin{array}{l}\rightarrow \\
\rightarrow\end{array}$} & MA & $M A$ & $M A$ & $M A$ & MA & MA & $M A$ & $M A$ & MA & $M A$ & MA & MA & $M A$ & MA & $M A$ & MA & $M A$ \\
\hline & & & $R A$ & $R A$ & $R O$ & $R A$ & $R A$ & $R O$ & $R A$ & $I W$ & $R A$ & $I W$ & $R O$ & $R A$ & $I W$ & $R A$ & $I W$ & $I W$ & $R O$ \\
\hline \multirow{2}{*}{\multicolumn{2}{|c|}{ Distances }} & & $\mathrm{Y}$ & Y & $\mathrm{Y}$ & $\mathrm{Y}$ & $\mathrm{N}$ & $\mathrm{Y}$ & Y & Y & $\mathrm{N}$ & $\mathrm{N}$ & Y & Y & $\mathrm{Y}$ & $\mathrm{N}$ & $\mathrm{N}$ & Y & Y \\
\hline & & Isi & k1 & k2 & k3 & k4 & k5 & k6 & k7 & k8 & k9 & k10 & k11 & k12 & k13 & k14 & k15 & k16 & k17 \\
\hline Alto Araguaia & \begin{tabular}{|l|} 
IT1 \\
\end{tabular} & j1 & 1759 & 1306 & --- & --- & --- & --- & --- & --- & --- & --- & --- & --- & --- & --- & --- & --- & --- \\
\hline Alvorada & \begin{tabular}{|l|} 
IT2 \\
\end{tabular} & j2 & --- & --- & --- & 1651 & 1651 & --- & 1570 & --- & 1570 & --- & --- & 1944 & --- & 1944 & --- & --- & --- \\
\hline Peixe & IT3 & j3 & --- & --- & --- & --- & --- & --- & --- & 1913 & --- & 1913 & --- & --- & --- & --- & --- & --- & --- \\
\hline Conceição do Araguaia & IT4 & $\mathrm{j} 4$ & --- & --- & --- & --- & --- & --- & --- & 1913 & --- & 1913 & --- & --- & --- & --- & --- & --- & --- \\
\hline Marabá 1 & IT5 & $\mathrm{j} 5$ & --- & -- & --- & --- & --- & --- & --- & 593 & --- & 593 & --- & --- & --- & --- & --- & -- & -- \\
\hline Marabá 2 & IT6 & $\mathrm{j} 6$ & --- & -- & --- & 734 & 734 & --- & 653 & --- & 653 & --- & --- & --- & --- & --- & --- & -- & -- \\
\hline Santa Rosa & IT7 & j7 & --- & -- & -- & --- & --- & --- & --- & --- & --- & --- & --- & --- & 1059 & --- & 1059 & -- & --- \\
\hline Porto Velho - A & IT8 & $\mathrm{j} 8$ & --- & --- & --- & --- & --- & --- & --- & --- & --- & --- & --- & --- & --- & --- & --- & 990 & --- \\
\hline Porto Velho - B & IT9 & j9 & --- & --- & --- & --- & --- & --- & --- & --- & --- & --- & --- & --- & --- & --- & --- & 990 & --- \\
\hline Lucas do Rio Verde & IT10 & j10 & --- & --- & --- & 2481 & 2481 & --- & 2400 & --- & 2400 & --- & --- & 1354 & --- & 1354 & --- & --- & --- \\
\hline Cuiabá & IT11 & j11 & --- & --- & --- & 2722 & 2722 & --- & 2641 & --- & 2641 & --- & --- & 1595 & --- & 1595 & --- & --- & --- \\
\hline Itaqui & IT12 & j12 & --- & --- & 0 & --- & --- & --- & --- & --- & --- & --- & --- & --- & --- & --- & --- & --- & --- \\
\hline Barcarena & IT13 & j13 & --- & --- & --- & --- & --- & 0 & --- & --- & --- & --- & --- & --- & --- & --- & --- & --- & --- \\
\hline Santarém & IT14 & j14 & --- & --- & --- & --- & --- & --- & --- & --- & --- & --- & 0 & --- & --- & --- & --- & --- & --- \\
\hline Manaus & IT15 & j15 & --- & --- & --- & --- & --- & --- & --- & --- & --- & --- & --- & --- & --- & --- & --- & --- & 0 \\
\hline
\end{tabular}

\subsubsection{Subproblem 3}

In subproblem 3, there are no restrictions on the connectivity of exportation and importation 
ports. The exportation port-importation port distance matrix is shown in Table 5. An asterisk in Table 5 denotes either port capacity expansion or new port development.

Table 5. Distances matrix of exportation ports and importation ports

\begin{tabular}{|l|c|c|c|c|c|c|}
\hline \multicolumn{2}{|c|}{ Importation Port $\mathbf{~}$} & Rotterdam & Malaga & Shanghai & Singapore \\
\hline \multicolumn{2}{|c|}{ Distances } & I1 & I2 & I3 & I4 \\
\hline \multicolumn{2}{|c|}{ Exportation Port } & km & IP1 & IP2 & IP3 & IP4 \\
\hline Paranagua & EP1 & k1 & 10,585 & 8,910 & 20,228 & 16,029 \\
Santos & EP2 & k2 & 10,331 & 8,664 & 20,136 & 15,943 \\
Itaqui & EP3 & k3 & 7,630 & 6,077 & 22,482 & 24,945 \\
Itaqui* & EP4 & k4 & 7,630 & 6,077 & 22,482 & 24,945 \\
Barcarena & EP5 & k5 & 7,766 & 6,297 & 22,149 & 24,780 \\
Barcarena* & EP6 & k6 & 7,766 & 6,297 & 22,149 & 24,780 \\
Santarem & EP7 & k7 & 8,357 & 6,916 & 22,787 & 25,167 \\
Santarem* & EP8 & k8 & 8,357 & 6,916 & 22,787 & 25,167 \\
Itacoatiara & EP9 & k9 & 9,037 & 7,596 & 23,467 & 25,847 \\
Manaus & EP10 & k10 & 9,201 & 7,760 & 23,631 & 26,011 \\
\hline
\end{tabular}

Table 6. Cost factor of transportation modes

\begin{tabular}{|l|c|}
\hline \multicolumn{1}{|c|}{ Modal } & USD/ton.km \\
\hline Road & 0.0613 \\
Rail & 0.0291 \\
Inland Waterways & 0.0132 \\
Maritime & 0.0016 \\
\hline
\end{tabular}

Unit transportation costs for each transportation mode are summarised in Table 6, which is based on Santos Lopes et al (2015). It is worth noting that Santos Lopes et al (2015) employ average transport costs related to rail and waterway transport based on the year 2013 .

\subsubsection{Input Data}

In this Subsection, input data that are used in the solution of the mathematical programming model are presented.

\subsubsection{Production Centres}

The input data employed for production amounts $\left(\mathrm{d}_{\mathrm{i}}, \mathrm{i}=1, \ldots, 7\right)$ in production centres are representative values of the harvest season pair 2015/2016 and 2016/2017. These values are summarised in Table 7 (IMEA, 2015 \& 2016). 
Table 7. Production amount in production centres

\begin{tabular}{|c|c|c|c|c|c|}
\hline \multicolumn{3}{|c|}{ Production Center } & & \multirow{2}{*}{$\begin{array}{c}\begin{array}{c}\text { Production } \\
\text { Amount 15/16 }\end{array} \\
1,737,776\end{array}$} & \multirow{2}{*}{$\begin{array}{c}\begin{array}{c}\text { Production } \\
\text { Amount 16/17 }\end{array} \\
1,828,800\end{array}$} \\
\hline Aripuaná & PC1 & i1 & & & \\
\hline Alto Floresta & PC2 & i2 & 0.85 & 807,095 & 894,543 \\
\hline Querência & PC3 & i3 & 4.5 & $4,200,783$ & $4,771,568$ \\
\hline Sorriso & PC4 & i4 & 10 & $9,085,526$ & $10,067,904$ \\
\hline Sapezal & PC5 & i5 & 3.5 & $3,534,131$ & $3,547,122$ \\
\hline Cuiabá & PC6 & i6 & 2.1 & $1,987,075$ & $2,113,271$ \\
\hline \multirow[t]{2}{*}{ Rondonópolis } & PC7 & i7 & 6.15 & $6,144,741$ & $6,162,044$ \\
\hline & Total & $\mathrm{M}$ ton & 28.9 & $27,497,127$ & $29,385,252$ \\
\hline
\end{tabular}

\subsubsection{Intermodal Terminal Input Data}

The input data employed for intermodal terminals are: unit opportunity costs $(\mathrm{Pj})$, unit handling cost $(\mathrm{Wj})$, maximum flow capacity (Capj), and installation cost $(\mathrm{Fj})$, and are summarised in Table 8 (Tribuna do Norte, 2011 \& THIAGO, F. et al, 2014 \& Secretaria Nacional de Portos, 2015). It is worth noting that the unit handling cost lies in the range 4-15 $\mathrm{R} \$$ /ton. The chosen value for unit handling cost for intermodal terminal RO/RA is $3 \mathrm{USD} /$ ton and for intermodal terminal $\mathrm{RO} / \mathrm{HI}$ is $2.5 \mathrm{USD} /$ ton. The unit opportunity cost is chosen equal to $0.5 \mathrm{USD}$ /ton. Furthermore, sources of other intermodal terminals are as the following: waterway intermodal parameters (Tribuna do Norte, 2011), rail intermodal parameters (THIAGO, F. et al, 2014), and maximum flow capacity (Secretaria Nacional de Portos, 2015)

Table 8. Parameters of intermodal terminals

\begin{tabular}{|c|c|c|c|c|c|c|c|c|c|c|c|c|c|c|c|c|c|}
\hline \multicolumn{3}{|c|}{ Intermodal Terminal IT } & IT1 & IT2 & IT3 & IT4 & IT5 & IT6 & IT7 & IT8 & IT9 & IT10 & IT11 & IT12 & IT13 & IT14 & IT15 \\
\hline Unit $\mathrm{P}$ & & nit & j1 & j2 & j3 & j4 & j5 & $\mathrm{j} 6$ & j7 & j8 & ز9 & j10 & j11 & j12 & j13 & j14 & $\mathrm{j} 15$ \\
\hline 의 & Pj & /ton & 0.5 & 0.5 & 0.5 & 0.5 & 0.5 & 0.5 & 0.5 & 0.5 & 0.5 & 0. & 0.5 & 0.5 & 0.5 & 0.5 & 0.5 \\
\hline & $\mathrm{u}$ & ton & 3.0 & 3.0 & 3.0 & 3.0 & 3.0 & 3.0 & 3.0 & 3.0 & 2. & 3.0 & 3.0 & 3.0 & 3.0 & 3.0 & 3.0 \\
\hline Iximum Flow Capaci & Capj & & 10 & 4 & 2 & 2 & 2 & 2 & 3 & 2 & 1.5 & & 2 & 1 & 0.45 & 0.4 & 0.86 \\
\hline Installation Cost & $\mathrm{Fj}$ & I USD & 0 & 140 & 30 & 80 & 0 & & 120 & 0 & 52.5 & 70 & 70 & o & 0 & 0 & 0 \\
\hline
\end{tabular}

\subsubsection{Production Centre-intermodal Terminal Unit Transportation Costs}

The input data for production centre-intermodal terminal unit transportation costs (Rij) are determined as the products of distance values in Table 2 and conversion factors in Table 6, and are shown in Table 9. Broken dash lines in Table 9 depict the inexistence of a transportation link between the production centre-intermodal terminal pair in question. 
Table 9. Unit Transportation Cost Rij

\begin{tabular}{|c|c|c|c|c|c|c|c|c|c|c|c|c|c|c|c|c|c|}
\hline \multicolumn{3}{|c|}{ Intermodal Terminal IT } & IT1 & IT2 & IT3 & IT4 & IT5 & IT6 & IT7 & IT8 & IT9 & IT10 & IT11 & \begin{tabular}{|l|} 
IT12 \\
\end{tabular} & IT13 & IT14 & IT15 \\
\hline \multirow{2}{*}{\multicolumn{2}{|c|}{$\begin{array}{c}\text { Type of Intermodal } \\
\text { Terminal }\end{array}$}} & \multirow{2}{*}{$\rightarrow$} & $R A$ & $R A$ & $I W$ & $I W$ & $R A$ & IW & $I W$ & IW & $I W$ & $R A$ & $R A$ & MA & MA & $M A$ & $M A$ \\
\hline & & & $R O$ & RO & RO & RO & RO & RO & $R O$ & RO & $R A$ & RO & $R O$ & RO & $R O$ & RO & $R O$ \\
\hline \multirow{2}{*}{\multicolumn{2}{|c|}{$\begin{array}{c}\text { Unit Transportation } \\
\text { Cost Rij }\end{array}$}} & $\rightarrow$ & $Y$ & $\mathrm{~N}$ & $\mathrm{~N}$ & $\mathrm{~N}$ & $\mathrm{Y}$ & 1 & $\mathrm{~N}$ & 1 & $\mathrm{~N}$ & $\mathrm{~N}$ & $\mathrm{~N}$ & 1 & - & $\mathrm{Y}$ & $\mathrm{Y}$ \\
\hline & & USD/ton & j1 & $\mathrm{j} 2$ & j3 & $\mathrm{j4}$ & $\mathrm{j5}$ & j6 & j7 & j8 & j9 & $\mathrm{j10}$ & $\mathrm{j} 11$ & $\mathrm{j} 12$ & $\mathrm{j} 13$ & j14 & j15 \\
\hline Aripuaná & PC1 & i1 & --- & --- & --- & --- & --- & --- & 23.1 & --- & --- & --- & --- & --- & --- & 106.0 & -- \\
\hline to Florest & PC2 & $\mathrm{i2}$ & --- & --- & --- & --- & --- & --- & 18.4 & --- & --- & --- & --- & --- & --- & 74.8 & --- \\
\hline Querência & PC3 & i3 & 56.2 & 29.8 & 38.8 & 53.7 & 68.5 & 69.2 & --- & --- & --- & --- & 51.2 & 129.0 & 101.6 & 162.4 & 201.3 \\
\hline Sorriso & PC4 & i4 & 52.3 & 101.9 & 104.6 & 119.5 & 134.3 & 135.0 & 47.3 & 104.1 & --- & 4.0 & 25.7 & 194.8 & 167.3 & 85.5 & 150.7 \\
\hline Sapezal & PC5 & i5 & 70.4 & 120.0 & 127.6 & 142.5 & 157.3 & 158.0 & 96.6 & 59.6 & --- & 45.3 & 43.8 & 217.8 & 190.3 & 134.9 & 106.3 \\
\hline Cuiabá & PC6 & i6 & 26.6 & 76.2 & 83.8 & 98.7 & 113.5 & 114.2 & 68.9 & 103.4 & 34.6 & 21.6 & 0.0 & 174.0 & 146.6 & 111.2 & 150.1 \\
\hline Rondonópolis & PC7 & i7 & 12.7 & 68.4 & 76.0 & 90.9 & 105.7 & 106.4 & 82.8 & 117.3 & --- & 35.6 & 13.9 & 166.2 & 138.8 & 125.1 & 164.0 \\
\hline
\end{tabular}

\subsubsection{Exportation Port Input Data}

The input data employed for exportation ports are: unit opportunity cost $\left(\mathrm{P}_{\mathrm{k}}\right)$, unit handling cost $\left(\mathrm{W}_{\mathrm{k}}\right)$, maximum flow capacity $\left(\mathrm{Cap}_{\mathrm{k}}\right)$, and installation cost $\left(\mathrm{F}_{\mathrm{k}}\right)$, and are summarised in Table 10 which is based on (Secretaria Nacional de Portos, 2015 \& Revista Portuária, 2017 \& VALEC, 2017 \& COMPANHIA DOCAS DO PARÁ, 2016). As in Subsection 3.1.4.2, the unit handling cost lies in the range $4-15 \mathrm{R} \$ /$ ton. The chosen values for unit handling cost for exportation port RO/MA are $3 \mathrm{USD} /$ ton, for exportation port RA/MA is $2 \mathrm{USD} /$ ton, and for exportation port HI/MA is $2 \mathrm{USD} /$ ton. The unit opportunity cost is chosen equal for all of the intermodal terminals based on an own criteria, $0.5 \mathrm{USD} /$ ton. Other input data for exportation ports are as follows.

Maximum flow capacity (Secretaria Nacional de Portos, 2015)

Installation cost parameters (Revista Portuária, 2017)

Handling cost (VALEC, 2017 \& COMPANHIA DOCAS DO PARÁ, 2016)

Table 10. Parameters of exportation ports

\begin{tabular}{|c|c|c|c|c|c|c|c|c|c|c|c|c|c|c|c|c|c|c|c|c|}
\hline \multicolumn{2}{|c|}{ Exportation Port EP } & EP1 & EP2 & EP3A & EP3B & EP4 & EP5A & EP5B & EP5B & EP6A & EP6B & EP7A & EP7B & EP7C & EP8A & EP8B & EP9 & EP10 \\
\hline \multicolumn{2}{|c|}{ Unit Parameter } & Unit & $\mathbf{k} 1$ & $\mathbf{k 2}$ & $\mathbf{k 3}$ & $\mathbf{k 4}$ & $\mathbf{k 5}$ & $\mathbf{k 6}$ & $\mathbf{k 7}$ & $\mathbf{k 8}$ & $\mathbf{k 9}$ & $\mathbf{k 1 0}$ & $\mathbf{k 1 1}$ & $\mathbf{k 1 2}$ & $\mathbf{k 1 3}$ & $\mathbf{k 1 4}$ & $\mathbf{k 1 5}$ & $\mathbf{k 1 6}$ & $\mathbf{k 1 7}$ \\
\hline Opportunity Cost & $\mathbf{P k}$ & USD/ton & 0.5 & 0.5 & 0.5 & 0.5 & 0.5 & 0.5 & 0.5 & 0.5 & 0.5 & 0.5 & 0.5 & 0.5 & 0.5 & 0.5 & 0.5 & 0.5 & 0.5 \\
Handling Cost & $\mathbf{W k}$ & USD/ton & 2.0 & 2.0 & 3.0 & 2.0 & 2.0 & 3.0 & 2.0 & 2.0 & 2.0 & 2.0 & 3.0 & 2.0 & 2.0 & 2.0 & 2.0 & 2.0 & 3.0 \\
\hline Maximum Flow Capacity & $\mathbf{C a p k}$ & $\mathbf{M}$ ton & 17 & 30 & 3.35 & 3.35 & 1.9 & 0.9 & 0.9 & 0.9 & 3 & 4 & 0.8 & 0.8 & 0.8 & 0.5 & 4 & 3.5 & 0.86 \\
\hline Installation Cost & $\mathbf{F k}$ & $\mathbf{M}$ USD & 0 & 0 & 0 & 0 & 95 & 0 & 0 & 0 & 150 & 200 & 0 & 0 & 0 & 25 & 200 & 0 & 0 \\
\hline
\end{tabular}

\subsubsection{Intermodal Terminal-Exportation Port Unit Transportation Costs}

The input data for production centre-intermodal terminal unit transportation costs $\left(\mathrm{R}_{\mathrm{ij}}\right)$ are determined as the products of distance values in Table 4 and conversion factors in Table 6 , and are shown in Table 11. Zero values in Table 9 depict the fact that the exportation port in question functions as an intermodal terminal as well. 
Table 11. Unit transportation cost Rjk

\begin{tabular}{|c|c|c|c|c|c|c|c|c|c|c|c|c|c|c|c|c|c|c|c|}
\hline \multicolumn{3}{|c|}{ Exportation Port EP } & EP1 & EP2 & EP3A & EP3B & EP4 & EP5A & EP5B & EP5B & EP6A & EP6B & EP7A & EP7B & EP7C & EP8A & EP8B & EP9 & EP10 \\
\hline \multirow{2}{*}{\multicolumn{2}{|c|}{ Type of Exportation Port }} & & $M A$ & $M A$ & $M A$ & $M A$ & $M A$ & $M A$ & $M A$ & $M A$ & $M A$ & $M A$ & $M A$ & $M A$ & $M A$ & $M A$ & $M A$ & $M A$ & $M A$ \\
\hline & & & $R A$ & $R A$ & $R O$ & $R A$ & $R A$ & $R O$ & $R A$ & $I W$ & $R A$ & $I W$ & $R O$ & $R A$ & $I W$ & $R A$ & $I W$ & $I W$ & $R O$ \\
\hline \multirow{2}{*}{\multicolumn{2}{|c|}{ Unit Transportation Cost Rjk }} & $\rightarrow$ & $\mathrm{Y}$ & $\mathrm{Y}$ & $\mathrm{Y}$ & $Y$ & $\mathrm{~N}$ & $\mathrm{Y}$ & Y & Y & $\mathrm{N}$ & $\mathrm{N}$ & Y & $Y$ & Y & $\mathrm{N}$ & $\mathrm{N}$ & Y & Y \\
\hline & & USD/ton & k1 & k2 & k3 & k4 & k5 & k6 & k7 & k8 & k9 & k10 & k11 & k12 & k13 & k14 & k15 & k16 & k17 \\
\hline \multirow{5}{*}{$\begin{array}{l}\text { Alto Araguaia } \\
\text { Alvorada } \\
\text { Peixe } \\
\text { Conceição do Araguaia } \\
\text { Marabá } 1\end{array}$} & IT1 & j1 & 51.2 & 38.0 & --- & --- & --- & --- & --- & --- & --- & --- & --- & --- & --- & --- & --- & --- & --- \\
\hline & IT2 & j2 & --- & --- & --- & 48.0 & 48.0 & --- & 45.7 & --- & 45.7 & --- & --- & 56.6 & --- & 56.6 & --- & --- & --- \\
\hline & IT3 & j3 & --- & --- & --- & --- & --- & --- & --- & 25.3 & --- & 25.3 & --- & --- & --- & --- & --- & --- & --- \\
\hline & IT4 & $\mathrm{j} 4$ & --- & --- & --- & --- & --- & --- & --- & 25.3 & --- & 25.3 & --- & --- & --- & --- & --- & --- & --- \\
\hline & IT5 & $\mathrm{j5}$ & --- & --- & --- & --- & --- & --- & --- & 7.8 & --- & 7.8 & --- & --- & --- & --- & --- & --- & --- \\
\hline \multirow{2}{*}{$\begin{array}{l}\text { Marabá } 2 \\
\text { Santa Rosa }\end{array}$} & IT6 & j6 & --- & --- & --- & 21.4 & 21.4 & --- & 19.0 & --- & 19.0 & --- & --- & --- & --- & --- & --- & --- & --- \\
\hline & IT7 & j7 & --- & --- & --- & --- & --- & --- & --- & --- & --- & --- & --- & --- & 14.0 & --- & 14.0 & --- & --- \\
\hline \multirow{3}{*}{$\begin{array}{l}\text { Porto Velho - A } \\
\text { Porto Velho - B } \\
\text { Lucas do Rio Verde }\end{array}$} & IT8 & j8 & --- & --- & --- & --- & --- & --- & --- & --- & --- & --- & --- & --- & --- & --- & --- & 13.1 & --- \\
\hline & IT9 & j9 & --- & --- & --- & --- & --- & --- & --- & --- & --- & --- & --- & --- & --- & --- & --- & 13.1 & --- \\
\hline & IT10 & $\mathrm{j} 10$ & --- & --- & --- & 72.2 & 72.2 & --- & 69.8 & --- & 69.8 & --- & --- & 39.4 & --- & 39.4 & --- & --- & --- \\
\hline \multirow{2}{*}{$\begin{array}{l}\text { Cuiabá } \\
\text { Itaqui }\end{array}$} & IT11 & j11 & --- & --- & --- & 79.2 & 79.2 & --- & 76.9 & --- & 76.9 & --- & --- & 46.4 & --- & 46.4 & --- & --- & --- \\
\hline & IT12 & j12 & --- & --- & 0.0 & --- & --- & --- & --- & --- & --- & --- & --- & --- & --- & --- & --- & --- & --- \\
\hline Barcarena & IT13 & j13 & --- & --- & --- & --- & --- & 0.0 & --- & --- & --- & --- & --- & --- & --- & --- & --- & --- & --- \\
\hline \multirow{2}{*}{$\begin{array}{l}\text { Santarém } \\
\text { Manaus }\end{array}$} & IT14 & j14 & --- & --- & --- & --- & --- & --- & --- & --- & --- & --- & 0.0 & --- & --- & --- & --- & --- & --- \\
\hline & IT15 & j15 & --- & --- & --- & --- & --- & --- & --- & --- & --- & --- & --- & --- & --- & --- & --- & --- & 0.0 \\
\hline
\end{tabular}

\subsubsection{Importation port input data}

The input data employed for importation ports are: unit handling cost (Wl) and maximum flow capacity (DEMl), and are summarised in Tables 12-14 (IMEA, 2015 \& 2016).

Table 12. Parameters of importation ports

\begin{tabular}{|c|c|c|c|c|c|c|}
\hline \multicolumn{2}{|c|}{ Importation Port IP } & IP1 & IP2 & IP3 & IP4 \\
\hline \multicolumn{2}{|c|}{ Unit Parameter } & Unit & I1 & I2 & I3 & I4 \\
\hline Handling Cost & WI & USD/ton & 2.0 & 2.0 & 3.0 & 2.0 \\
Maximum Flow Capacity & Deml & M ton & 1.2 & 1.35 & 9.9 & 0.7 \\
\hline
\end{tabular}

Table 13. Unit transportation cost Rk1

\begin{tabular}{|l|c|c|c|c|c|c|}
\hline \multicolumn{2}{|c|}{ Importation Port $\rightarrow$} & Rotterdam & Malaga & Shanghai & Singapore \\
\hline \multicolumn{2}{|c|}{ Unit Transportation Cost RkI } & IP1 & IP2 & IP3 & IP4 \\
\hline \multicolumn{2}{|c|}{ Exportation Port } & USD/ton & I1 & I2 & I3 & I4 \\
\hline Paranagua & EP1 & k1 & 16.9 & 14.3 & 32.4 & 25.6 \\
Santos & EP2 & k2 & 16.5 & 13.9 & 32.2 & 25.5 \\
Itaqui & EP3 & k3 & 12.2 & 9.7 & 36.0 & 39.9 \\
Itaqui* & EP4 & k4 & 12.2 & 9.7 & 36.0 & 39.9 \\
Barcarena & EP5 & k5 & 12.4 & 10.1 & 35.4 & 39.6 \\
Barcarena* & EP6 & k6 & 12.4 & 10.1 & 35.4 & 39.6 \\
Santarem & EP7 & k7 & 13.4 & 11.1 & 36.5 & 40.3 \\
Santarem* & EP8 & k8 & 13.4 & 11.1 & 36.5 & 40.3 \\
Itacoatiara & EP9 & k9 & 14.5 & 12.2 & 37.5 & 41.4 \\
Manaus & EP10 & k10 & 14.7 & 12.4 & 37.8 & 41.6 \\
\hline
\end{tabular}




\section{Macrothink}

Table 14. Importation port demand

\begin{tabular}{|c|c|c|c|}
\hline \multicolumn{3}{|c|}{ Importation Port } & DEM \\
\hline Rotterdam & IP1 & I1 & 1.2 \\
\hline Malaga & IP2 & 12 & 1.35 \\
\hline Shanghai & IP3 & 13 & 9.9 \\
\hline Singapore & IP4 & 14 & 0.7 \\
\hline & & & 13.15 \\
\hline
\end{tabular}

\subsubsection{Output Data}

Employing the input data presented in Subsection 3.1.4, each subproblem has been solved using the LINGO solver version 17 (Lindo Systems, 2016). The results obtained are summarised in the following Subsections. The solutions obtained for submodels 1, 2, and 3 are all optimal global solutions.

\subsubsection{Submodel 1}

The results obtained from the solution of submodel 1 are shown in detail in Table 15. As it may be observed in Table 15, twelve intermodal terminals have been selected for opening, out of a total of fifteen potential ones. It is worth noting that of the selected subset of intermodal terminals, two (IT8 and IT9) possess inland waterway exits. The optimal logistics infrastructure investment and transportation operating costs are 382.65 and 2,108.62 MUSD, respectively.

Table 15. Output data of Subproblem 1

\begin{tabular}{|c|c|c|c|c|c|c|c|c|c|c|c|c|c|c|c|}
\hline & IT1 & IT2 & IT3 & IT4 & IT5 & IT6 & IT7 & IT8 & IT9 & IT10 & IT11 & IT12 & IT13 & IT14 & IT15 \\
\hline$Y j$ & 1 & 1 & 0 & 0 & 1 & 1 & 1 & 1 & 1 & 0 & 1 & 1 & 1 & 1 & 1 \\
\hline$x(i, j)$ & j1 & j2 & j3 & $\mathrm{j} 4$ & j5 & j6 & j7 & j8 & j9 & $\mathrm{j} 10$ & j11 & j12 & j13 & j14 & j15 \\
\hline i1 & 0 & 0 & 0 & 0 & 0 & 0 & 1 & 0 & 0 & 0 & 0 & 0 & 0 & 0 & 0 \\
\hline i2 & 0 & 0 & 0 & 0 & 0 & 0 & 1 & 0 & 0 & 0 & 0 & 0 & 0 & 0 & 0 \\
\hline i3 & 0 & 0,022 & 0 & 0 & 0 & 0 & 0 & 0 & 0 & 0 & 0,376 & 0,222 & 0,100 & 0,089 & 0,191 \\
\hline i4 & 0,620 & 0,180 & 0 & 0 & 0,200 & 0 & 0 & 0 & 0 & 0 & 0 & 0 & 0 & 0 & 0 \\
\hline i5 & 0 & 0,429 & 0 & 0 & 0 & 0 & 0 & 0,571 & 0 & 0 & 0 & 0 & 0 & 0 & 0 \\
\hline i6 & 0 & 0,286 & 0 & 0 & 0 & 0 & 0 & 0 & 0,714 & 0 & 0 & 0 & 0 & 0 & 0 \\
\hline i7 & 0,618 & 0 & 0 & 0 & 0 & 0,325 & 0,057 & 0 & 0 & 0 & 0 & 0 & 0 & 0 & 0 \\
\hline
\end{tabular}

\begin{tabular}{|c|c|c|c|c|c|c|c|c|c|c|c|c|c|c|c|}
\hline $\mathrm{dj}$ & 10 & 4 & 0 & 0 & 2 & 2 & 3 & 2 & 1.5 & 0 & 2 & 1 & 0.45 & 0.4 & 0.86 \\
\hline
\end{tabular}

\begin{tabular}{|l|c|c|}
\hline $\mathrm{Z1}$ & 382.65 & M USD \\
$\mathrm{Z2}$ & 2108.62 & $\mathrm{M}$ USD \\
\hline
\end{tabular}

\subsubsection{Submodel 2}

The results obtained from the solution of submodel 2 are shown in detail in Table 16. As it 
may be observed from Table 16, eleven exportation ports have been selected for opening out of a total of seventeen potential ones, sixteen of which are located in the northern and northereastern regions of Brazil, which is a desired result of the optimal redesign of the soybean grain supply chain under consideration in this paper. The optimal logistics investment and transportation operating costs are 556.63 and 935.61 MUSD, respectively.

Table 16. Output data of Subproblem 2

\begin{tabular}{|c|c|c|c|c|c|c|c|c|c|c|c|c|c|c|c|c|c|}
\hline & EP1 & EP2 & EP3A & EP3B & EP4 & EP5A & EP5B & EP5B & EP6A & EP6B & EP7A & EP7B & EP7C & EP8A & EP8B & EP9 & EP10 \\
\hline$Y \mathbf{k}$ & 0 & 1 & 1 & 1 & 0 & 1 & 1 & 0 & 1 & 1 & 1 & 1 & 0 & 0 & 1 & 1 & 1 \\
\hline$X(j, k)$ & k1 & k2 & k3 & k4 & k5 & k6 & k7 & k8 & k9 & k10 & k11 & k12 & k13 & k14 & k15 & k16 & k17 \\
\hline j1 & 0 & 1 & 0 & 0 & 0 & 0 & 0 & 0 & 0 & 0 & 0 & 0 & 0 & 0 & 0 & 0 & 0 \\
\hline $\mathrm{j} 2$ & 0 & 0 & 0 & 0,562 & 0 & 0 & 0 & 0 & 0,238 & 0 & 0 & 0,200 & 0 & 0 & 0 & 0 & 0 \\
\hline j3 & 0 & 0 & 0 & 0 & 0 & 0 & 0 & 0 & 0 & 1 & 0 & 0 & 0 & 0 & 0 & 0 & 0 \\
\hline j4 & 0 & 0 & 0 & 0 & 0 & 0 & 0 & 0 & 1 & 0 & 0 & 0 & 0 & 0 & 0 & 0 & 0 \\
\hline j5 & 0 & 0 & 0 & 0 & 0 & 0 & 0 & 0 & 0 & 0 & 0 & 0 & 0 & 0 & 1 & 0 & 0 \\
\hline j6 & 0 & 0 & 0 & 0 & 0 & 0 & 0 & 0 & 0 & 0 & 0 & 0 & 0 & 0 & 0 & 1 & 0 \\
\hline j7 & 0 & 0 & 0 & 0 & 0 & 0 & 0 & 0 & 0 & 0 & 0 & 0 & 0 & 0 & 0 & 1 & 0 \\
\hline j8 & 0 & 0 & 0 & 0,550 & 0 & 0 & 0,450 & 0 & 0 & 0 & 0 & 0 & 0 & 0 & 0 & 0 & 0 \\
\hline j9 & 0 & 0 & 1 & 0 & 0 & 0 & 0 & 0 & 0 & 0 & 0 & 0 & 0 & 0 & 0 & 0 & 0 \\
\hline j10 & 0 & 0 & 0 & 0 & 0 & 1 & 0 & 0 & 0 & 0 & 0 & 0 & 0 & 0 & 0 & 0 & 0 \\
\hline j11 & 0 & 0 & 0 & 0 & 0 & 0 & 0 & 0 & 0 & 0 & 1 & 0 & 0 & 0 & 0 & 0 & 0 \\
\hline j12 & 0 & 0 & 0 & 0 & 0 & 0 & 0 & 0 & 0 & 0 & 0 & 0 & 0 & 0 & 0 & 0 & 1 \\
\hline
\end{tabular}

\begin{tabular}{|l|l|l|l|l|l|l|l|l|l|l|l|l|l|l|l|l|l|}
$\mathrm{dk}$ & 0 & 10 & 1 & 3.35 & 0 & 0.45 & 0.9 & 0 & 2.95 & 2 & 0.4 & 0.8 & 0 & 0 & 3 & 3.5 & 0.86 \\
\hline
\end{tabular}

\begin{tabular}{|l|l|l|l|}
\hline Z3 & 556.63 & M USD \\
\hline Z4 & 935.61 & M USD \\
\hline
\end{tabular}

\subsubsection{Submodel 3}

The results obtained from the solution of submodel 3 are shown in detail in Table 17. From Table 17, it may be seen that whilst the port of Santos $(\mathrm{k}=1)$ continues providing soybean grain to the ports of Shanghai and Singapore, no soybean grain flows through it to the ports of Rotterdam and Malaga. This is an important contribution of the optimal redesign of the soybean grain supply chain under consideration in this paper, in view of the heavy congestion at the port of Santos, and consequent long delivery time and substantial grain loss in the waiting process for loading at the port of Santos. At the same time, the northern and northeastern ports $(\mathrm{k}=2, \ldots, 7)$ play a significant role in meeting demand at all importation ports, with the exception of Singapore. This is also another important result of the optimal redesign of the soybean grain supply chain under consideration in this paper. As may be observed from Table 17, the optimal transportation operating cost is 609.38 MUSD. 
Table 17. Output data of Subproblem 3

\begin{tabular}{|c|c|c|c|c|}
\hline & IP1 & IP2 & IP3 & IP4 \\
\hline $\mathbf{x}(\mathbf{k}, \mathbf{l})$ & 11 & 12 & 13 & 14 \\
\hline k1 & 0 & 0 & 0,930 & 0,070 \\
\hline k2 & 0 & 1 & 0 & 0 \\
\hline k3 & 0 & 1 & 0 & 0 \\
\hline k4 & 0 & 0,879 & 0,121 & 0 \\
\hline k5 & 1 & 0 & 0 & 0 \\
\hline k6 & 0 & 1 & 0 & 0 \\
\hline k7 & 0 & 1 & 0 & 0 \\
\hline k8 & 0 & 1 & 0 & 0 \\
\hline
\end{tabular}

\begin{tabular}{|l|l|l|l|}
\hline Z5 & 609.38 & M USD \\
\hline
\end{tabular}

\subsubsection{Present Situation}

The present (nonoptimal) situation of the soybean grain supply chain under consideration in this paper functions solely with the existent intermodal terminals and is heavily dependent on the road transportation mode. The present situation is shown in detail in Tables 18-21. As may been seen in Table 21, the current operation cost is 3,980.51 MUSD.

Table 18. Unit transportation costs at present time between PC-EP

\begin{tabular}{|c|c|c|c|c|c|c|c|c|}
\hline \multicolumn{2}{|c|}{$\begin{array}{c}\text { Unit Transportation Cost } \\
\text { PC - EP (USD/ton) }\end{array}$} & Paranagua & Santos & Itaqui & Barcarena & Santarem & Itacoatiara & Manaus \\
\cline { 2 - 9 } & EP1 & EP2 & EP3 & EP4 & EP5 & EP6 & EP7 \\
\hline Aripuaná & PC 1 & 0 & 0 & 0 & 0 & 1059877,0 & 0 & 0 \\
Alto Floresta & PC 2 & 0 & 96.9 & 0 & 0 & 74786,0 & 0 & 0 \\
Querência & PC 3 & 0 & 0 & 129 & 0 & 0 & 0 & 0 \\
Sorriso & PC 4 & 0 & 90.3 & 0 & 0 & 0 & 0 & 0 \\
Sepazal & PC 5 & 0 & 0 & 0 & 0 & 0 & 72.7 & 0 \\
Cuiabá & PC 6 & 0 & 64.6 & 0 & 0 & 0 & 0 & 150.1 \\
Rondonópolis & PC 7 & 0 & 50.7 & 166.2 & 138.8 & 0 & 0 & 0 \\
\hline
\end{tabular}

Table 19. Transportation amounts at present time between PC-EP.

\begin{tabular}{|c|c|c|c|c|c|c|c|c|}
\hline \multirow{2}{*}{\multicolumn{2}{|c|}{$\begin{array}{c}\text { Transportation Amount } \\
\text { PC - EP (M ton) }\end{array}$}} & Paranagua & Santos & Itaqui & Barcarena & Santarem & Itacoatiara & Manaus \\
\hline & & EP1 & EP2 & EP3 & EP4 & EP5 & EP6 & EP7 \\
\hline Aripuaná & PC 1 & 0 & 0 & 0 & 0 & 1.8 & 0 & 0 \\
\hline Alto Floresta & PC 2 & 0 & 0.25 & 0 & 0 & 0.6 & 0 & 0 \\
\hline Querência & PC 3 & 0 & 0 & 4.5 & 0 & 0 & 0 & 0 \\
\hline Sorriso & PC 4 & 0 & 10 & 0 & 0 & 0 & 0 & 0 \\
\hline Sepazal & PC 5 & 0 & 0 & 0 & 0 & 0 & 3.5 & 0 \\
\hline Cuiabá & PC 6 & 0 & 1.24 & 0 & 0 & 0 & 0 & 0.86 \\
\hline Rondonópolis & PC 7 & 0 & 0.95 & 2.5 & 2.7 & 0 & 0 & 0 \\
\hline \multicolumn{2}{|c|}{ Handling Amount (M ton) } & 0,00 & 12.44 & 7,00 & 2.7 & 2.4 & 3.5 & 0.86 \\
\hline \multicolumn{2}{|c|}{ Unit Handling Cost (USD/ton) } & 2 & 2 & 3 & 3 & 3 & 2 & 3 \\
\hline
\end{tabular}


Table 20. Unit transportation costs at present time between EP-IP

\begin{tabular}{|c|c|c|c|c|c|}
\hline \multicolumn{2}{|c|}{$\begin{array}{c}\text { Unit Transportation Cost } \\
\text { EP - IP (USD/ton) }\end{array}$} & Rotterdam & Malaga & Shanghai & Singapore \\
\cline { 2 - 6 } & IP1 & IP2 & IP3 & IP4 \\
\hline Paranagua & EP1 & 16.9 & 14.3 & 32.4 & 25.6 \\
Santos & EP2 & 16.5 & 13.9 & 32.2 & 25.5 \\
Itaqui & EP3 & 12.2 & 9.7 & 36 & 39.9 \\
Barcarena & EP4 & 12.4 & 10.1 & 35.4 & 39.6 \\
Santarem & EP5 & 13.4 & 11.1 & 36.5 & 40.3 \\
Itacoatiara & EP6 & 14.5 & 12.2 & 37.5 & 41.4 \\
Manaus & EP7 & 14.7 & 12.4 & 37.8 & 41.6 \\
\hline
\end{tabular}

Table 21. Transportation amounts at present time between EP-IP

\begin{tabular}{|c|c|c|c|c|c|}
\hline \multicolumn{2}{|c|}{$\begin{array}{c}\text { Transportation Amount } \\
\text { EP - IP (M ton) }\end{array}$} & Rotterdam & Malaga & Shanghai & Singapore \\
\cline { 2 - 6 } & IP1 & IP2 & IP3 & IP4 \\
\hline Paranagua & EP1 & 0 & 0 & 0 & 0 \\
Santos & EP2 & 0 & 0 & 12.4 & 0 \\
Itaqui & EP3 & 0 & 0 & 0 & 7 \\
Barcarena & EP4 & 2.7 & 0 & 0 & 0 \\
Santarem & EP5 & 0 & 2.4 & 0 & 0 \\
Itacoatiara & EP6 & 0 & 3.5 & 0 & 0 \\
Manaus & EP7 & 0.86 & 0 & 0 & 0 \\
\hline \multicolumn{2}{|l}{ Handling Amount (M ton) } & $\mathbf{3 . 5 6}$ & $\mathbf{5 . 9}$ & $\mathbf{1 2 . 4}$ & $\mathbf{7}$ \\
\hline \multicolumn{2}{|l}{ Unit Handling Cost (USD/ton) } & $\mathbf{2}$ & $\mathbf{2}$ & $\mathbf{3}$ & $\mathbf{2}$ \\
\hline
\end{tabular}

\section{\begin{tabular}{|l|l|l|l|l} 
Current Operational Cost & 3980.51 & M USD
\end{tabular}}

\subsubsection{Comparison of Present Supply Chain Design and Proposed Optimal Redesign}

For the purpose of comparing the present situation, which is based on a nonoptimal supply chain design, with the proposed optimal redesign, Table 22 is provided. As may be observed from Table 21, there is a reduction of 326.90 MUSD in transportation operating cost through an investment cost of 939.28 MUSD. This implies a payback period of approximately three years, and consequently generating profits from the fourth year onwards. This demonstrates the advantages of the optimal redesign of the soybean grain supply chain under consideration in this paper. 


\section{Macrothink}

Table 22. Comparison between present situation and optimal redesigned supply chain

\begin{tabular}{|c|c|c|c|c|c|c|c|}
\hline Optimal Redesign & \multicolumn{3}{|c|}{ Investment } & \multicolumn{3}{|c|}{ Operational Cost } & \multirow[b]{2}{*}{ M USD } \\
\hline Sub problema 1 & $\mathbf{Z 1}$ & 212.5 & 382.65 & $\mathbf{Z 2}$ & 2249.33 & 2108.62 & \\
\hline Sub problema 2 & $\mathrm{Z3}$ & 505.00 & 556.63 & $\mathbf{Z 4}$ & 741.89 & 935.61 & M USD \\
\hline Sub problema 3 & & & & $\mathrm{Z5}$ & 561.05 & 609.38 & M USD \\
\hline Total & & Tota & 939.28 & & Total & 3653.61 & M USD \\
\hline Present Situation & & & & & & 3980.51 & M USD \\
\hline & & & Reductio & Ope & onal Cost & 326.90 & M USD \\
\hline
\end{tabular}

\subsection{Uncertainty and Sensitivity Analysis}

Of all the input parameter data that are necessary to solve submodels 1,2 , and 3, the principal parameter which possesses a significant uncertainty is the cost of opportunity that is associated with unused handling capacity of intermodal terminals and exportation ports that are selected for opening in solving submodels 1 and 2, respectively. This is because all other input parameters depict factors which correspond to real conditions of installations and transportation links and whose values are estimated with a low level of uncertainty, in contradistinction to the opportunity cost which is usually estimated by the assessment of the project portfolio investments that are available for the investor, whereby the soybean grain supply chain redesign project is but one of several project investment options. An order of magnitude sensitivity analysis has been carried out on the opportunity cost input parameter, by variation of its value in the range $0.5-5.0 \mathrm{USD} / \mathrm{ton}$, recalling that 0.5 is the base value used in the solution of subproblems 1 and 2; cf., Tables 8 and 10.

The results of the aforesaid order of magnitude sensitivity analysis of the opportunity cost are summarised in Table 23, where the variation of the five objective functions $\left(\mathrm{z}_{1}, \mathrm{z}_{2}, \mathrm{z}_{3}, \mathrm{z}_{4}, \mathrm{z}_{5}\right)$ with opportunity cost is shown, along with operating cost (OP Cost $=z_{2}+z_{4}+z_{5}$ ), the difference between optimal operating cost and present situation operating cost (OP Var), the corresponding differences for two and three years (OP Var 2x and OP Var 3x), and investment $\operatorname{cost}\left(\mathrm{z}_{1}+\mathrm{z}_{3}\right)$. It is worth noting that for the opportunity cost range studied, the same subsets of intermodal terminals and exportation ports are selected for opening. 
Table 23. Sensitivity analysis results

\begin{tabular}{|c|c|c|c|c|c|c|c|c|c|c|}
\hline Pj & Z1 & Z2 & Z3 & Z4 & Z5 & OP Cost & OP Var & OP Var 2x & OP Var 3x & Investment \\
\hline 0.5 & 382.65 & 2108.62 & 556.63 & 935.61 & 609.38 & 3653.61 & 326.9 & 653.80 & 980.7 & 939.28 \\
\hline 1.0 & 382.81 & 2039.97 & 563.25 & 935.61 & 609.38 & 3584.96 & 395.55 & 791.10 & 1186.65 & 946.06 \\
\hline 1.5 & 382.96 & 1843.32 & 569.88 & 935.61 & 609.38 & 3388.31 & 592.2 & 1184.4 & 1776.6 & 952.84 \\
\hline 2.0 & 383.12 & 2242.97 & 576.5 & 935.61 & 609.38 & 3787.96 & 192.55 & 385.10 & 577.7 & 959.62 \\
\hline 2.5 & 383.27 & 2234.76 & 583.13 & 935.61 & 609.38 & 3779.75 & 200.76 & 401.52 & 602.3 & 966.4 \\
\hline 3.0 & 383.43 & 1861.78 & 589.75 & 935.61 & 609.38 & 3406.77 & 573.74 & 1147.48 & 1721.22 & 973.18 \\
\hline 3.5 & 383.58 & 2071.74 & 596.38 & 935.61 & 609.38 & 3616.73 & 363.78 & 727.56 & 1091.34 & 979.96 \\
\hline 4.0 & 383.74 & 2273.00 & 603.00 & 935.61 & 609.38 & 3817.99 & 162.52 & 325.04 & 487.56 & 986.74 \\
\hline 4.5 & 383.89 & 2465.25 & 609.63 & 935.61 & 609.38 & 4010.24 & -29.73 & -59.5 & -89.2 & 993.52 \\
\hline 5.0 & 384.05 & 2465.25 & 616.25 & 935.61 & 609.38 & 4010.24 & -29.73 & -59.5 & -89.2 & 1000.3 \\
\hline
\end{tabular}

The variation of each of the five objective functions $\left(\mathrm{z}_{1}, \mathrm{z}_{2}, \mathrm{z}_{3}, \mathrm{z}_{4}, \mathrm{z}_{5}\right)$ with opportunity cost is shown in Fig.1. As can be seen from Fig.1, each objective function shows a slightly increasing linear variation in all objective functions, with the exception of the production centre-intermodal terminal transportation operating cost (z2), which oscillates in the range 2000-2500 MUSD. The variation of OP Cost, OP Var, OP Var 2x, OP Var 3x, and investment are shown in Fig.2. The variation of OP Var assumes negative values for opportunity cost greater than 4.0 USD/ton, which implies non attractive investment. Be that as it may, OPVar assumes maximum values at opportunity costs of 1.5 and $3.0 \mathrm{USD} / \mathrm{ton}$, reflecting profit potential. Considering the variation of OP Var $2 x$, investment recovery occurs in two years at opportunity cost values of 1.5 and 3.0 USD/ton. Similarly, considering the variation of OP Var 3x, investment recovery occurs in three years at opportunity cost values of 1.0 and 3.5 USD/ton. It should be recalled that these observations may serve as a basis for a more elaborated investment appraisal, taking into account the time value of money.

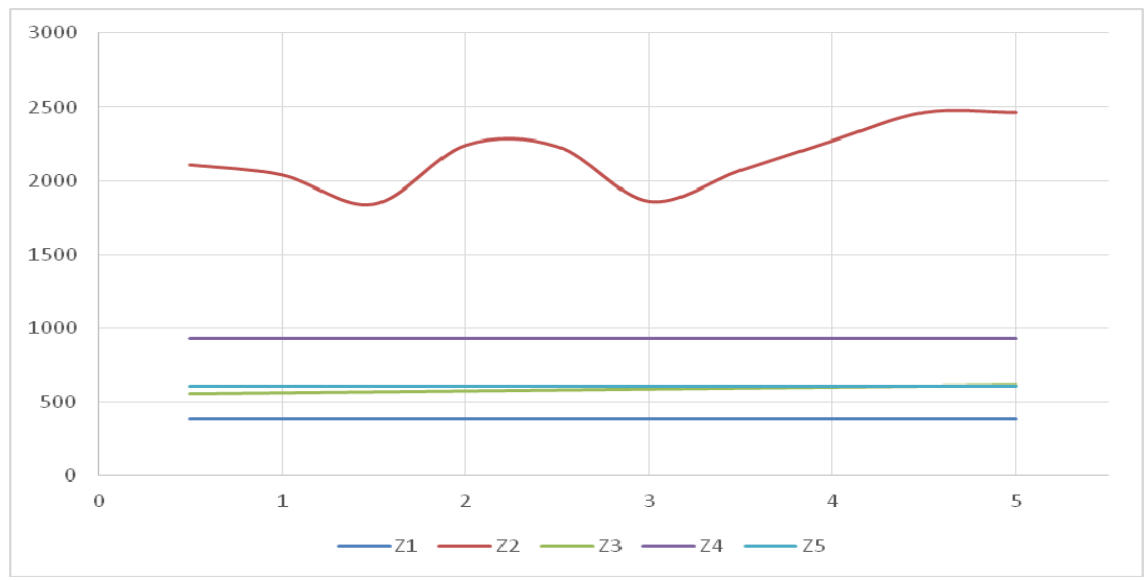

Figure 1. Variation of objective functions with opportunity cost 


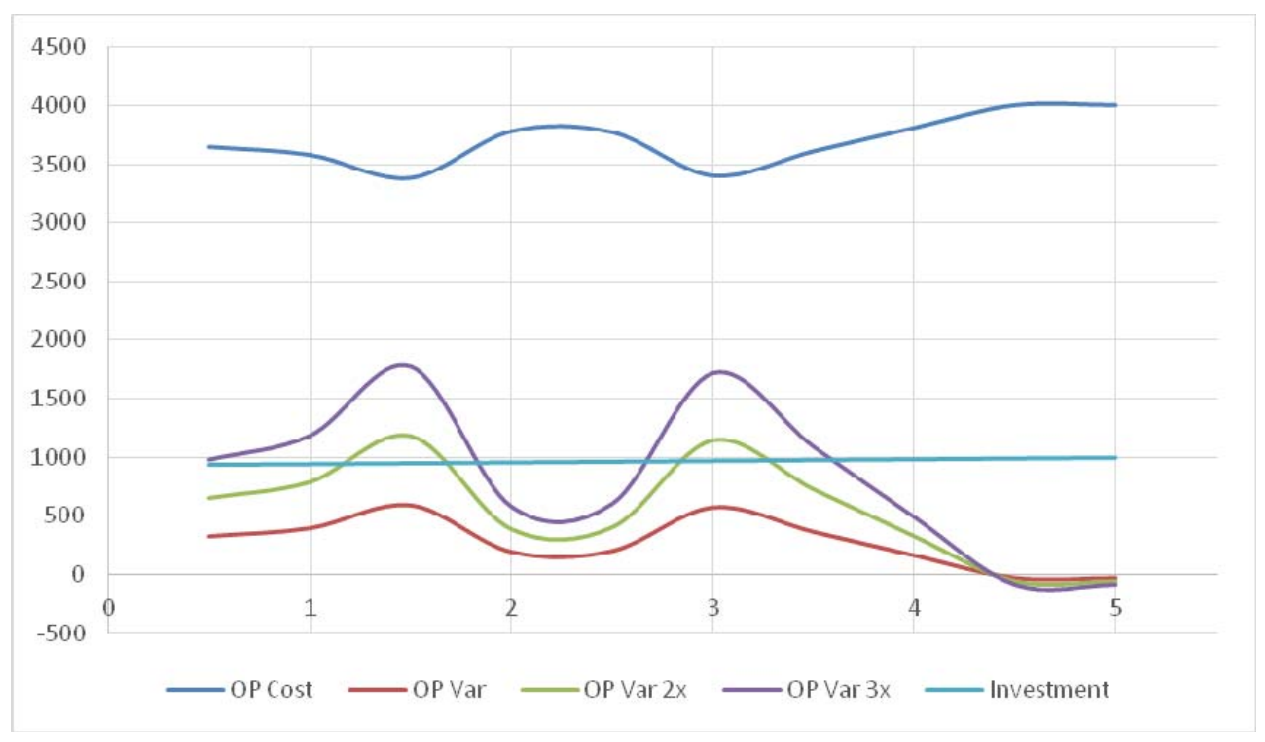

Figure 2.Variation of operating costs with opportunity cost

\section{Discussion}

Motivated by the leading position of Brazil, along with the US, of soybean grain production andv exportation in the world, and the necessity of substantial improvement in its global four echelon soybean grain supply chain, a mathematical programming model is presented in this paper. In view of its complexity and intractability, the model is decomposed into three submodels, two of which are bilivel programming submodels in order to take into account the two levels of decision making with regard to logistics infrastructure investment cost at the second and third levels of the supply chain and operating logistics and transportation cost at and between all echelons of the supply chain. The three submodels are applied to a real life case study of the State of Mato Grosso, which is the leader in soybean production and exportation in Brazil, and a global optimal solution is obtained for the redesign of the existent supply chain. The results obtained show that in two to three years, the logistics infrastructure investment is recovered with a concomittant susbstantial decrease in logistics and transportation operating costs.

The novel modelling decomposition approach presented in this paper possesses general applicability to multiple supply chains where there are two decision makers at one or more echelon in the supply chain. However, it cannot be overemphasized that whilst global optimal solutions have been obtained for the decomposed model, there is no guarantee that this is the global optimal solution of the the original undecomposed model. In the way of a recommendation for future research work, a heuristic iterative algorithm, based on the model decomposition approach presented in this paper, needs to be developed and tested on a real life case study, with a view to obtain solutions which may be closer to the flobal optimal solution of the original undecomposed model of the problem under consideration. 


\section{References}

Bahinipati, B. K., Kanda, A., \& Deshmukh, S. G. (2009). Coordinated supply management; review, insights, and limitations International Journal of Logistics: Research and and Applications, 12(6), 407-422.

Cao, D., \& Chen, M. (2006). Capacitated plant selection in a decentralized manufacturing environment: A bilevel optimization approach. European Journal of Operational Research, 169, 97-110.

Cao, D., \& Leung, L. C. (2002). A partial cooperation model for non-unique linear two-level decision problems. European Journal of Operational Research, 140, 134-141.

Clott, C., Hartman, B. C., Ogard, E., \& Gatto, A. (2015). Container repositioning and agricultural commodities: Shipping soybeans by container from US hinterland to overseeas markets. Research in Transportation Business and Management, 14, 56-65.

Companhia Docas do Pará. (2016). Tarifa companhia docas do Pará. ANTAQ. [Online] Available:

http://www.antaq.gov.br/Portal/TarifasPortuarias/Pdf/TarifasPortuariasBelemOuteiro.pdf

Cortinhal, M. J., Lopes, M. G., \& Melo, M. J. (2014). Dynamic design and re-design of multi-echelon, multi-product logistics networks with outsourcing opportunities: A computational study. Computers and Industrial Engineering, 90, 118-131.

Fliehr, O. (2014). Analysis of transportation and logistics processes for soybeans in Brazil. Thünen Working Paper 4, Thünen Instute of Farm Economics, Braunschweig, Germany.

Ghaderi, H., Pishavee, M. S., \& Moini, A. (2016). Biomass supply chain network design: Na optimization-oriented review and analysis. Industrial Crops and Products, 94, 972-1000.

Handfield, R. B., \& Nichols, L. (2002). Supply Chain Redesign: Transforming Supply Chains into Integrated Value Systems. Upper Saddle River, NJ: Financial Times Prentice Hall.

Hyland, M. F., Mahmassani, H. S., \& Mijahed, L. B. (2016). Analytical models of rail transportation service in the grain supply chain: Deconstructing the operational and economic advantages of shuttle train service. Transportation Research Part E, 93, 294-315.

Ibrahim, H. W., Zulaini, S., \& Tan, K. C. (2015). A content analysis of global supply chain research. Benchmarking: An International Journal, 22(7), 1429-1462.

IMEA-Instituto Mato-grossense de Economia Agropecuária. 2015 \& 2016. Boletins semanais.

[Online]

Available:

http://www.imea.com.br/imea-site/relatorios-mercado-detalhe? $\mathrm{c}=4 \& \mathrm{~s}=2$

Nagurney, A. (2010). Optimal supply chain network design and redesign at minimal cost and with demand satisfaction. International Journal of Production Economics, 128(1), 200-208.

Reis, S. A., \& Leal, J. E. (2015). A deterministic mathematical model to support temporal and spatial decisions of the soybean supply chain. Journal of Transport Geography, 43, 48-58. 
Revista Portuária. (2017). Mais um porto em Santa Catarina. [Online] Available: http://www.revistaportuaria.com.br/blog/18372

Santos Lopes, H., Costa Ferreira, R., \& Da Silva Lima, R. (2015). Logística da soja brasileira para exportação: modelo de otimização orientado para a minimização de custos logíticos. XXIX Congresso Nacional de Pesquisa em Transporte da ANPET. Ouro Preto-MG.

SECRETARIA NACIONAL DE PORTOS. (2015). Sistema Portuário Nacional. Ministério dos transportes, portos e aviação civil. [Online] Available: https://webportos.labtrans.ufsc.br/Brasil/Index\#

Taylor, R. D., \& Koo, W. W. (2015). 2015 outlook of yje U.S. and world corn and soybean industries, 2014-2024. Agribusiness and Applied Esconomics Report no. 741, Center for Agricultural Policy and Trade Studies, Department of Agribusiness and Applied Economics, North Dakota State University, USA.

Thiago, F. (2014). Criação de novos terminais intermodais e seus impactos: Um estudo na região de Alto Araguaia”. ENGEMA. [Online] Available: http://www.engema.org.br/XVIENGEMA/442.pdf

Thomas, A., Krishnamoorthy, M., Singh, G., \& Vaenkateswaram, J. (2015). Coordination in a multiple producers-distributers supply chain and the value of information. International Journal of Production Economics, 167, 61-73.

Tribuna do norte. (2011). Precisamos de um porto que possa receber navios maiores. 06-11-2011.

[Online]

Available:

http://www.tribunadonorte.com.br/noticia/precisamos-de-um-porto-que-possa-receber-navios -maiores/201828

VALEC. (2017). Pátio, intermodal de porto franco-MA. [Online] Available: http://www.valec.gov.br/OperacoesPatiosPortoFrancoMA.php

Van Der Vorst, J. G. A. J., \& Buelens, J. M. (19990. A research model for the redesign of food supply chains. International Journal of Logistics Research and Applications, 2(2), 161-174.

Yeh, K., Realff, M. J., Lee, J. H., \& Whittaker, C. (2014). Analysis and comparison of single period single level and bilevel programming representations of a pre-existing timberlands supply chain with a new biorefunery facility. Computers and Chemical Engineering, 68, 242-254.

Yeh, K., Whottaker, C., Realff, M., \& Lee, J. H. (2015). Two stage stochastic bilevel programming model of a pre-established timberlands supply chain with biorefinery investment interests. Computers and Chemical Engineering, 73, 141-153.

Zhang, D., Zhan, Q., Chen, Y., \& Li, S. (2016). Joint optimization of logistics infrastructure investments and subsidies in a regional logistics network with $\mathrm{CO}_{2}$ emission reduction targets. Transportation Research Part D. 2016. http://doi.org/10.1016/j.trd.2016.02.019

Zucchi, J. D., Zeng, A. Z., \& Caixeta-Filho, J. V. (2013). Optimum location for 


\section{Macrothink}

export-oriented slaughterhouses in Mato Grosso, Brazil: a dynamic mathematical model. International Journal of Logistics: Research and Applications, 14(3), 135-148.

\section{Appendix A.}

\section{Notation}

$i$ - index for production centre; $i \in I$

$\mathrm{j}$ - index for intermodal terminal; $\mathrm{j} \in \mathrm{J}$

$\mathrm{k}$ - index for exportation port; $\mathrm{k} \in \mathrm{K}$

1 - index for importation port; $1 \in \mathrm{L}$

$\mathrm{JJ}$ - set of intermodal terminals that are opened

KK - set of exportation ports that are opened

$\mathrm{d}_{\mathrm{i}}-$ production quantity in production centre $\mathrm{i}$

$\mathrm{d}_{\mathrm{jj}}$ - handled quantity that is handled in intermodal terminal that are opened $\mathrm{jj}$

$\mathrm{d}_{\mathrm{kk}}$ - handled quantity that is handled in exportation port that are opened kk

$F_{j}$ - opening cost of intermodal terminal $j$

$\mathrm{F}_{\mathrm{k}}$ - opening cost of exportation port $\mathrm{k}$

$P_{j}$ - opportunity cost for unused handling capacity of intermodal terminal $j$

$\mathrm{P}_{\mathrm{k}}$ - opportunity cost for unused handling capacity of exportation port $\mathrm{k}$

$\mathrm{W}_{\mathrm{j}}$ - unit handling cost in intermodal terminal $\mathrm{j}$

$\mathrm{W}_{\mathrm{k}}$ - unit handling cost in exportation port $\mathrm{k}$

$\mathrm{R}_{\mathrm{ij}}$ - unit transportation cost from production centre $\mathrm{i}$ to intermodal terminal $\mathrm{j}$

$\mathrm{R}_{\mathrm{jj}, \mathrm{k}}$ - unit transportation cost from intermodal terminal $\mathrm{jj}$ to exportation port $\mathrm{k}$

$\mathrm{R}_{\mathrm{kk}, 1}$ - unit transportation cost from exportation port kk to importation port 1

$\mathrm{Cap}_{\mathrm{j}}$ - available handling capacity of intermodal terminal $\mathrm{j}$

$\mathrm{Cap}_{\mathrm{k}}$ - available handling capacity of exportation port $\mathrm{k}$

Dem $_{1}$ - demand quantity at importation port 1

$\mathrm{X}_{\mathrm{ij}}$ - continuous decision variable corresponding to the fraction of production quantity of production centre $\mathrm{i}$ that is handled in intermodal terminal $\mathrm{j}$

$\mathrm{X}_{\mathrm{jj}, \mathrm{k}}$ - continuous decision variable corresponding to the fraction of handled quantity in intermodal terminal $\mathrm{jj}$ that is handled in exportation port $\mathrm{k}$ 


\section{Macrothink}

Business and Management Horizons

ISSN 2326-0297

2017, Vol. 5, No. 2

$\mathrm{X}_{\mathrm{kk}, 1}$ - continuous decision variable corresponding to the fraction handled quantity in exportation port $\mathrm{kk}$ that is hanled in inportation port 1

$\mathrm{Y}_{\mathrm{j}}$ - binary decision variable which $=1$ if intermodal terminal $\mathrm{j}$ is selected and opened, and which $=0$ otherwise

$\mathrm{Y}_{\mathrm{k}}$ - binary decision variable which $=1$ if exportation port $\mathrm{k}$ is opened, and which $=0$ otherwise

$\mathrm{IS}_{\mathrm{i}}$ - group of production center $\mathrm{i}$ that are linked to intermodal terminal $\mathrm{j}$

$\mathrm{JS}_{\mathrm{j}}$ - set of intermodal terminal $\mathrm{j}$ that are available for production center $\mathrm{i}$

$\mathrm{JJS}_{\mathrm{jj}}$ - group of intermodal terminal $\mathrm{jj}$ that are linked to exportation port $\mathrm{k}$

$\mathrm{KS}_{\mathrm{k}}$ - set of exportation port $\mathrm{k}$ that are available for intermodal terminal $\mathrm{jj}$

\section{Appendix B.}

\section{MLP model of Chen and Cao (2006)}

Minimise $z_{1}=\sum_{i=1, \ldots, m} f_{i} y_{i}+\sum_{i=1, \ldots, m} p_{i}\left(C a p_{i} y_{i}-\sum_{j \in I S i} d_{j} a_{i j} x_{i j}\right)$

subject to

$\sum_{\mathrm{i} \in \mathrm{JSj}} \mathrm{x}_{\mathrm{ij}}=1, \mathrm{j}=1, \ldots, \mathrm{n}$

$\sum_{\mathrm{j} \in I S i} d_{j} a_{i j} x_{i j} \leq \operatorname{Cap}_{i} y_{i}, i=1, \ldots, m$

$\sum_{\mathrm{j} \in I S \mathrm{Ii}} \mathrm{x}_{\mathrm{ij}} \leq \mathrm{ny}_{\mathrm{i}}, \mathrm{i}=1, \ldots, \mathrm{m}$

$\beta_{\mathrm{i}} \leq \mathrm{Cap}_{\mathrm{i}} \mathrm{u}_{\mathrm{i}}+\mathrm{n} \mathrm{v}_{\mathrm{i}}-\mathrm{My}_{\mathrm{i}}+\mathrm{M}, \mathrm{i}=1, \ldots, \mathrm{m}$

$\beta_{\mathrm{i}} \geq \mathrm{Cap}_{\mathrm{i}} \mathrm{u}_{\mathrm{i}}+\mathrm{nv}_{\mathrm{i}}, \mathrm{i}=1, \ldots, \mathrm{m}$

$\beta_{\mathrm{i}} \geq-\mathrm{M} \mathrm{y}_{\mathrm{i}}, \mathrm{i}=1, \ldots, \mathrm{m}$

$t_{j}+d_{j} a_{i j} u_{i}+v_{i} \leq w_{i} d_{j} a_{i j}+d_{j} R_{i j}, i=1, \ldots, m, j \in I S_{i}$

$\mathrm{t}_{\mathrm{j}} \in \mathrm{R}^{1}, \beta_{\mathrm{i}}, \mathrm{v}_{\mathrm{i}}, \mathrm{u}_{\mathrm{i}} \leq 0, \mathrm{x}_{\mathrm{i}} \geq 0, \mathrm{y}_{\mathrm{i}} \in\{0,1\}, \mathrm{i}=1, \ldots, \mathrm{m} \mathrm{j} \in \mathrm{IS}_{\mathrm{i}}$

\section{Copyright Disclaimer}

Copyright for this article is retained by the author(s), with first publication rights granted to the journal.

This is an open-access article distributed under the terms and conditions of the Creative Commons Attribution license (http://creativecommons.org/licenses/by/4.0/). 